\title{
Visiones de y en Ana de San Bartolomé (imágenes y textos)
}

Recibido: 16/02/2020. Aceptado: 29/07/2020.

\section{Resumen}

En este artículo se comparan textos, grabados y pinturas que interpretan el 'diálogo místico' de Ana de San Bartolomé con las imágenes. La iconografía religiosa representada en las obras de arte de los conventos carmelitanos, puebla los sueños y visiones que ella describe en su Autobiografía. También sus retratos la representan orando ante imaginería de culto, y documentan ese método de oración que consiste en asimilar y trascender imágenes mentales estimuladas por imágenes artísticas.

Palabras clave: Ana de San Bartolomé, imagen, visión mística, retrato, autobiografía.

\section{Visions of and in Anne of Saint Bartholomew (Images and Texts)}

\begin{abstract}
The aim of this article is to compare and contrast different texts, engravings and paintings representing Anna of St. Bartholomew's 'mystical dialogue' with religious images. The sacred iconography presented in works of art in convents are also in the dreams and visions described in her Autobiography. Also, many portraits that depict her praying facing religious imagery record a method for praying that consists in assimilating and transcending mental images stimulated by artistic ones.
\end{abstract}

Keywords: Anne of St. Bartholomew, image, mystic vision, portrait, autobiography.

1 Estudio financiado por la beca predoctoral MECD-FPU17/03735, dirigido por Lucía Lahoz en el marco del proyecto MINECO-HAR2017-85392-P/2018-2020 dirigido por Fernando González. El artículo se basa en la investigación previa a la ficha "Retrato de Ana de San Bartolomé” del catálogo coordinado por Mariano Casas (Muñoz, 2018, pp. 314-315). Desde aquí agradezco el impulso de los profesores Lucía Lahoz y Mariano Casas, quienes han facilitado materiales de estudio y bibliografía, así como a los revisores de AHAMM, cuyos apuntes y sugerencias también han quedado incorporados en el texto. 
“El entenderlo es verlo”.

Juan de la Cruz. ${ }^{2}$

En este ensayo vamos a tratar con textos e iconografías que representan el 'diálogo místico' de Ana de San Bartolomé con las imágenes. Las biografías de esta carmelita descalza, y sus retratos, muestran un método de oración que consiste en asimilar y trascender imágenes mentales estimuladas por imágenes artísticas. A partir de las premisas de estos 'ejercicios espirituales', procuraremos fragmentar un proceso que liga percepciones y producciones, para entender cómo esta autora y personaje de su biografía llega a convertirse en imagen de sí misma retroalimentando imaginaciones e imaginerías. Estos productos visuales, materiales e inmateriales, vehiculan imágenes con directrices ideológicas que proceden e incidieron en la sociedad conventual de esta beata y, al observarlas, apreciaremos mecanismos de imitación que engranan y confunden la realidad y el mundo de las representaciones. Se trata de imágenes: no tienen una única definición, consumen el significado de las cosas, representan ausencias y fantasmas (Blanchot, 1969), y así conforman identidades de los hombres y mujeres que piensan el mundo e intentan realizarse en él con y como imágenes (Belting, 2012).

\section{Preliminares}

Partícipes del énfasis de la imagen y lo material como medios de propagación ideológica y transmisión de conocimiento en la Contrarreforma (Ditchfield, 2017, pp. 164-195), en los carmelos descalzos del Siglo de Oro se practicaban métodos de comprensión basados en la contemplación: una tendencia a extraer el saber de las imágenes y a dar fe del mundo a través de ellas, similar a lo que se ha detectado en nuestro tiempo como norma del consumo de un "nuevo modo pixelado de intervisualidad" (Mirzoeff, 2003, p. 56). La intervisualidad no caracteriza a la 'postmodernidad': es un modo de interpretar y configurar imágenes a partir de otras imágenes, a base de asociaciones, y no caracteriza a una sola cultura; pero reconocer esas "citas visuales" (Burke, 2008, p. 33) implica comprender motivos, medios, estructuras, códigos de las sociedades que las generan y a las cuales se dirigen (Schmitt, 1999). El análisis de esos gestos miméticos de ida y vuelta, entre la realidad y las representaciones de los cuerpos históricos, artísticos y humanos, se apoya en reflexiones ahistóricas de la antropología, el psicoanálisis, la semiótica, conjugadas en la teoría contemporánea de la imagen. Esta enseña que, si bien las imágenes mentales se manifiestan gracias a medios técnicos verbales o visuales, sus productos surgen de la diversa y constante interacción entre imágenes y textos, y conforman representaciones siempre híbridas: intermediales (Mitchell, 2009). Por tanto, nuestro criterio de selección e interpretación de fragmentos escritos o pinturas no se basa en relaciones documentadas de producción entre ellos, sino que trata de captar las citas que los vinculan, los rasgos de analogía que señalen la dirección de los discursos que rigen las imágenes, en la coordenada del objeto y agente de ellas.

Ana de San Bartolomé fue compañera de Teresa de Jesús, y así conviene revisar la noción de 'visión mística' de las carmelitas descalzas, en el contexto de lo que Javier Portús ha definido como "compleja casuística de la imagen" en el Siglo de Oro. El auge del retrato, la biografía y la vera effigies, de tratados y doctrinas que codifican el lenguaje iconográfico, determinaron las artes contrarreformistas, dedicadas a promocionar la 'verdadera fe' en conventos donde se practicaban y teorizaban métodos de oración que propiciaban, a su vez, la multiplicación de imaginería (Portús, 2011, pp.

2 Subida al Carmelo II, 23 (De la Cruz, 1628, p. 182.) En esta bibliografía se notará el sesgo hispano que marca el propio tema de estudio; sería recomendable ahondar en otras tradiciones que lo enriquecen. 
37-47). El estudio de Lucía Lahoz sobre la relación de Teresa de Ávila con las imágenes ha puesto de relieve el peso de las tradiciones medievales sobre las que se asentaron esas "estrategias figurativas e imaginativas" (Lahoz, 2015, pp. 29-40; 2019, pp. 170193), ofreciendo una guía de abordaje a los retratos y memorias de esta otra mística.

A Ana García Manzanas (Almendral de la Cañada, 1549 - Amberes, 1626), una de las pupilas predilectas de Teresa, se la recuerda, como a ella, por ser triple vector de imágenes: receptora de imágenes divinales, productora de imágenes que testifican esas visiones -en cartas, textos doctrinales, poéticos, autobiografías que hablan de sus 'amores' con imágenes religiosas-y objeto de representaciones que retrataron su 'diálogo místico' (Lahoz, 2005, pp. 255-294). Estas pinturas y grabados, biografías y declaraciones, afianzaron y diversificaron iconografías y personajes de culto e historia de los descalzos, y así Ana se hizo icono en Flandes, en España y allá donde cundió la fe en la taumaturgia de sus rezos, de su cuerpo o 'reliquia viva', su retrato o 'verdadera imagen' (Urkiza, 1981, pp. 53-68; 2006, pp. 319-380; 2008, pp. 165-202; Yuste y Rivas-Caballero, 2004, pp. 301-345). ${ }^{3}$

Los extractos que comentaremos narran ese 'diálogo místico' de Ana con imágenes y objetos: reliquias y esculturas, a los que atribuyó poderes milagrosos, e iconos, figuras y personajes, que pueblan esos objetos y los sueños y visiones que relató en sus escritos. También sus retratos suelen representarla rezando ante la imaginería que estimuló sus imaginaciones. Recordemos que los escritos de Teresa, Agustín de Hipona o Juan de la Cruz instruyen en la creencia en una imagen que se ve en una pintura, una escultura, una música, palabra o sonido, un olor, gusto o tacto, y que las religiosas no solían debatir las razones teológicas de este fenómeno; Ana expresó sus efectos de manera vulgar y confiada: "un día se me apareçió el Señor en visión enteletual -que le sentí, mas no le vi-y díjome..." (Autobiografía A: 333). Eran los teóricos quienes procuraban explicar esa experiencia y justificarla como 'aprehensión del entendimiento' en la 'noche de la fe':

\begin{abstract}
Vissiones, Revelaciones, Locuciones y Sentimientos espirituales. A las quales llamamos puramente Espirituales, porque no, como las corporales y imaginarias, se comunican al Entendimiento por vía de los Sentidos corporales, sino, sin algún medio de algún Sentido corporal esterior ó interior, se ofrecen al Entendimiento clara y distintamente por vía sobrenatural pasivamente (...) todas estas quatro aprehensiones se pueden llamar Visiones del Alma, porque al entender del Alma llamamos, también, ver del alma. Y por quanto todas estas aprehensiones son inteligibles al Entendimiento, son llamadas visibles espiritualmente. $Y$ así, las inteligencias que dellas se forman en el Entendimiento, se pueden llamar visiones intelectuales (...) todo lo que se puede ver, y todo lo que se puede oír, y todo lo que se puede oler, y gustar, y tocar, son objetos del Entendimiento en quanto caen debajo de verdad o falsedad (...) Como habemos dicho, el entenderlo es verlo. 4
\end{abstract}

La visión intelectual o 'visión del alma' es una visión sin imagen o que trasciende la imaginación en una intelectualidad que niega la posibilidad de conocer a Dios mediante la razón. Las imágenes figurativas descritas en las biografías de Ana, en cambio, encajan

3 En los últimos años de su vida (1620-1624) Ana escribió dos autobiografías, la de Amberes (A) y la de Bolonia (B). Sus cartas, publicadas por Julen Urkiza (1985), suman 665. Crisóstomo Enríquez publicó su biografía en 1632, fuente documental junto al Proceso de beatificación y canonización editado por Monte Carmelo en 2010. La Autobiografía fue editada por Fortunato Antolín en Revista de Espiritualidad (1969). Urkíza publicó las Obras completas de la beata en 1981 y 1985 (Roma) y 1999 (Burgos) (aquí citamos la Autobiografía (A o B) por la edición de 1981, modificando al mínimo la transcripción). La compilación de Ángel Peña (2012) proporciona una selección de fragmentos útiles para el estudio visual. La Asociación de Amigos de la Beata (Urkiza dir.) recopila bibliografía en: www.anadesanbartolome.org. Hemos accedido al material gráfico del que hablaremos a través de la recopilación de Ruiz y Urkiza (2016), el catálogo Vitor Teresa coordinado por Mariano Casas (2019), el portal digital de la Biblioteca de la Universidad de Amberes y el de la Biblioteca Nacional de España.

4 Subida al Carmelo (De la Cruz, 1628, pp. 181-182). Caro Baroja (1985, pp. 125-144) comparó otras teorías y opiniones en torno a las imágenes, defendidas por los místicos de aquella época. 
entre las visiones imaginarias. Pero ambos tipos de 'visión' se relacionan entre sí a través de su correspondencia respectiva con dos modos de aproximación a lo sagrado, vigentes en la controversia teológica del siglo XVII: por un lado, la vía positiva de la imaginación, que utiliza analogías para tratar de definir a Dios, y por otro, la negativa de aquella espiritualidad sin palabra y cuya visión sin imagen era considerada superior a la visión imaginada -también por Teresa de Ávila, y aunque ella misma recomendase alcanzarla a través de la contemplación (Rodrigo, 2015, p. 650)-. La teología medieval ya conjugaba la vía positiva en dialéctica con la negativa, que se halla en los escritos de Dionisio Aeropagita y se remonta al judaísmo y al platonismo (Louth, 1998, pp. 71, 84). Para Barbara Mujica, la prosa metafórica de Teresa se caracteriza por esta misma tensión: conocía los Ejercicios espirituales de Ignacio de Loyola, que promueven la imagen como estímulo de una oración que produce experiencias místicas, así como el Alfabeto Espiritual de Francisco de Osuna que describe el 'recogimiento' y el 'movimiento interior del alma' hacia la 'unión con Dios' por medio de una meditación en tres niveles: oración verbal, oración mental y focalizada en imágenes, y finalmente, silenciosa hacia la comprensión más allá de imágenes y palabras; corresponden a las vías 'purgativa', 'iluminativa' y 'unitiva' de la mística del Aeropagita (Mujica, 2001, pp. 741-748): método incluido en las costumbres de los noviciados descalzos (Muñoz, 2020).

Una aspiración que motiva las testificaciones, escritas o representadas, de y sobre el don visionario de las místicas, es la santidad, que se procuraba a los candidatos a base de mostrar sus rasgos de humildad, obediencia, sencillez, caridad, devoción... escala de valores de conducta llevada a la práctica en los conventos. Esas virtudes podían ser premiadas -a los que no padecían 'sequedad espiritual'- por las inspiraciones divinales: la visión sin visión del rostro, sin rostro de lo divino, suponiendo que 'verlo' es entenderlo sin imágenes. Inscritos en esta práctica religiosa, y en pro del interés contrarreformista durante las guerras protestantes, el rostro, el retrato y las visiones de las místicas se promocionaron como ejemplo de santidad católica y prueba de su comunión con el 'Dios verdadero', pues, aunque las visiones de lo que no se puede ver nientender, en principio, plantean el problema de su interpretación plástica y literaria, fue la iconografía, codificada durante siglos por una Iglesia idoloclasta e iconofílica, el medio preferido para dirigir el entendimiento desde las contemplaciones a la visión de lo divino (Belting, 2012). Portús ha señalado la idoneidad de la imaginería barroca, con gran poder de persuasión, para la estimulación de estos ejercicios que modelaban la imaginación de quienes imitaban y modulaban los prototipos del arte con sus acciones, trazándose así lo que puede describirse como flujo semiótico de sensaciones, imágenes mentales y artísticas (González, 2010, p. 228).

\section{Imágenes que predeterminan la biografía}

Los mecanismos imitativos pueden apreciarse en la estructura argumental de la Autobiografía de Ana: responde a patrones de la hagiografía medieval y adapta elementos legendarios, ya desde el inicio de la historia, donde la protagonista se describe nacida en familia humilde, huérfana y pastora en el campo toledano que se convierte en escenario bucólico de sus visiones infantiles; estas la ponen a prueba, la comunican con Dios, que se desvela auténtico padre, y preconizan el camino a un calvario personal: un sacrificio conventual que impone los obstáculos que ha de superar hasta alcanzar su redención final (Autobiografía A, pp. 283-290). Ana decía que imitaba los modelos de la sociedad devota: "vámonos a ser ermitañas todas dos como la Madalena y otras que se an echo onbres" -animaba a su prima Francisca Cano, quien también se hizo monja siguiendo a Cristo- (Autobiografía B, p. 428). La vocación suponía obedecer 
a una biografía preestablecida en prototipos antiguos (Kris y Kurz, 1982) y coetáneos: Teresa era el ejemplo humano más cercano que Ana procuró obedecer. ${ }^{5}$

Un recurso argumental de la Autobiografía, relacionado con la asimilación de modelos icónicos, es la intervención divina (o diabólica) que justifica cambios en el desarrollo de la historia y evoluciones del personaje, como en las vidas de héroes y santos. Ana decía que las visiones le habían empujado a defender la idea de profesar en San José de Ávila -convento que acababa de fundar Teresa siendo ya un icono en ambientes devotos- $y$ que, como Teresa misma, "deseava padeçer travajos, desonras, y ser tenida por loca" (Autobiografía A, p. 286); así solicitó a las autoridades el ingreso en el descalzo y, ante la prohibición, veía monstruos y sombras divinas. En la Escena 6 del ciclo de estampas que se editaron en Alemania tras la muerte de Ana en Flandes, aparece la "multitud de demonios crueles -dice la inscripción- queriendo asustarla y hacerla volver atrás" (fig. 1) y, en la Escena 7, la Trinidad, en figura de tres jóvenes, los espanta (Ruiz y Urkiza, 2016, p. 57). ${ }^{6}$ Se dice que el cura del Almendral, llegado de Ávila, interpretó esas visiones y la dirigió al Carmelo, donde ingresa en 1570. Cuando la invistieron novicia, escogió su apellido de San Bartolomé en honor a otro milagro: la curación de aquellas aflicciones en una ermita. Por entonces Teresa estaba fundando el convento salmantino; volvió a San José en 1577; al llegar, llamó a Ana a su celda y desde entonces fueron inseparables (Autobiografía A, p. 287; Yuste y Rivas-Caballero, 2004, p. 311).

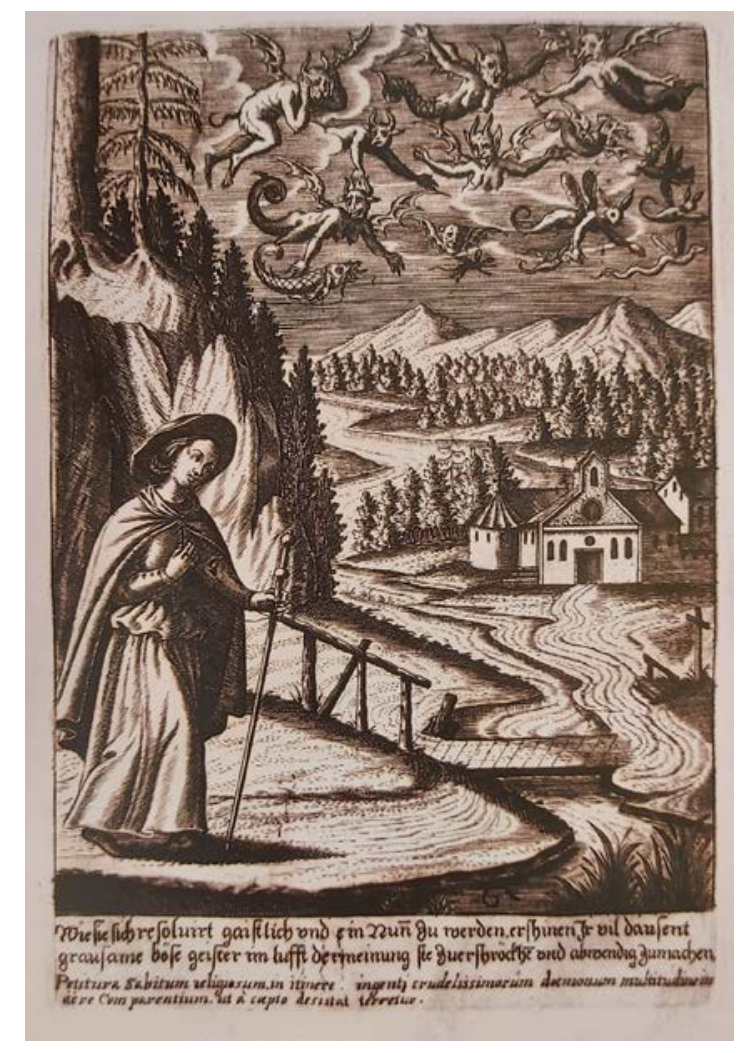

Figura 1. Anónimo. Estampa. Escena 6 del Ciclo de la Vida de Ana de San Bartolomé. ¿Colonia, post quem 1637? Carmelitas de Munich. [Fotografía: Ruiz y Urkiza, 2016, p. 55].

5 Ciertos pasajes y motivos que configuran el prototipo de santidad de la fundadora se repiten en la biografía de la beata (ambas dicen deber su entendimiento del latín a la inspiración divina), si bien difieren en algunos parámetros de fabricación hagiográfica (a la cuna humilde de la beata se opone la insistencia en la nobleza de Teresa). Véase Atienza (2015, pp. 575-612) y Herranz (2017, pp. 107-114).

6 Estas estampas de grabados a buril se conservan en el archivo provincial de los descalzos en Múnich. Ana M. Ruiz y Julen Urkiza aproximan su producción a Colonia post quem 1637. Respecto a la Escena 7, comentan el error cronológico que supone que Ana aparezca vestida de monja y no como lega que era todavía en el episodio de la Autobiografía. 
Ana y Teresa partieron de Ávila en 1580 y, tras el viaje fundacional, llegaron a Alba de Tormes, donde tuvo lugar la escena a partir de la cual Ana pudo esgrimir su testimonio en la lucha por la "legítima herencia de la verdadera espiritualidad teresiana": la muerte de la santa el 4 de octubre de 1582 . Cristina Valero ha señalado la escasez de representaciones conocidas de este episodio, sin embargo, tan recordado en la historia escrita de la orden; en ellas, Teresa suele aparecer con Cristo y los ángeles, Antonio de San José y Ana de San Bartolomé (Valero, 2014, p. 137). La Escena 14 del ciclo de estampas se compone como ella la describió: la madre muere en sus brazos y en presencia de Cristo, la Virgen y San Francisco (Ruiz y Urkiza, 2016, pp. 70-71). La pintura de Isabel Guerra, Yel almendro floreció (2008) (Ruiz, 2015, pp. 720-721), o la serie televisiva Teresa de Jesús (RTVE, 1984) (Díaz, 2015, p. 733), versionan este relato que propició la canonización de Teresa (1622) y la beatificación de Ana (1917).

La aprendiz asume desde entonces el papel de narradora de la historia de Teresa, contempladora de su espíritu, transmisora de su obra y testigo privilegiado de su misión: "que no es nada lo que se cuenta en sus libros". ${ }^{7}$ En sus cartas utilizó argumentos históricos y religiosos para describirse como 'auténtica heredera' tras haber pasado los últimos años de la madre a su vera. Por eso sus testimonios son tan útiles para los historiadores de la orden, aunque se han percatado de su parcialidad (Urkiza, 1981, pp. 55-111). Concepción Torres ha comparado la escritura de Ana con la de una de sus oponentes, Ana de Jesús, a quien los críticos definen como más intelectual y naturalista; cada una defendió una interpretación distinta de las Constituciones, ${ }^{8}$ pero fueron representadas bajo el mismo manto teresiano: sus rostros llegaron a los retablos de los Carmelitas de Burgos (Ibáñez y Payo, 2000-2002, pp. 267-297) y a las pinturas de Stella Maris en Haifa; son monjas excepcionales entre las descalzas por su privilegio de ser retratadas junto a la santa y formar así parte visible de la historia del Carmelo (Valero, 2014, p. 133).

Tras la muerte de Teresa, las disidencias estallaron en la 'revuelta de las monjas' que a Ana le producía -decía- aflicciones del espíritu. Aun así, animada por las visiones partió a Francia y fue nombrada priora de París y fundadora en Pontoise y Tours (16051608). Escribió haber cumplido esta misión impulsada por apariciones de la madre: "Una vez, en particular, vino a mí como si estuviera viva y me asió de la mano y me llevó por un largo camino fuera de Françia, y ansí fue que presto me vine a Flandes" (Autobiografía A: pp. 358-359). ${ }^{9}$ La visión legitimaba en la Autobiografía la fundación de Amberes (1612) y las versiones pictóricas hacían lo propio difundiendo el argumento de autoridad teresiana. La declaración de estos milagros impulsó el proceso de beatificación de Teresa (1614), tras el cual Ana pudo advocar el convento amberino a Teresa y San José, nombrar a su novicia Teresa de Jesús en otro gesto de transmisión y celebrar la canonización en la fiesta católica que conmemoró el programa de la monarquía española en Flandes (1622). Estas visiones le acompañaron durante las guerras protestantes en el priorato que mantuvo hasta morir en 1626 (Urkiza, 1981); así lo hace ver la Escena 20 del ciclo alemán, o la 18 que representa cómo "con frecuencia se le aparece la Madre resplandeciente como un sol" (Ruiz y Urkiza, 2016, p. 83).

\footnotetext{
7 Autobiografía A, p. 303, sobre las dificultades del viaje a Burgos.

8 El enfrentamiento se tensa a partir de las revocaciones de 1591 del papa Gregorio XIV al breve Salvatoris (1590) -el cual reafirmaba las constituciones redactadas por Teresa en contraposición de la nueva cúpula colegiada del Carmelo Descalzo denominado la Consulta- otorgado por su antecesor Sixto V (Torres, 1995; Atienza, 2016, pp. 229-242).

9 La función legitimadora de esta escena (la santa se le aparece con una maqueta de edificio gótico en la mano, que simboliza el convento amberino; Valero, 2014, p. 136) es análoga a la de otras composiciones que retratan visiones de la fundadora (Santa Teresa guiada por ángeles al monasterio de la Encarnación, Museo de Valencia, en Rodrigo, 2015, pp. 645-66o).
} 


\section{Ansí te quiero, sin ser ni saber nada, por açer por ti lo que yo quiero}

Muchas costumbres y enseñanzas en las clausuras donde Ana vivía se practicaban y transmitían por debajo del dominio de la cultura masculina. La retrospectiva feminista ha puesto de relieve esta distinción de sexo y género explícita en las representaciones plásticas así como en los textos de la época: "quando me persuadían que no viniese a Françia, y dezíanme que a qué abía de benir una muger que no sauía como los onbres predicar y enseñar, que para rezar sólo, desde allá lo pudía acer". ${ }^{10}$ Ana no fue sometida a la formación erudita del siglo, pero, como Teresa, siguió los "modelos y patrones femeninos" de un largo "linaje' de religiosas y ascetas medievales (Lahoz, 2015, pp. 64-65). Rocío Sánchez ha llamado la atención sobre el reciente interés historiográfico hacia 'el sexo débil' en el estudio de las artes plásticas, tras el feminismo que viene cuestionando los tópicos en torno al cuerpo (Sánchez, 2008, pp. 299-327), y Lucía Lahoz ha señalado que, también en el caso de Teresa, las herencias medievales de las prácticas religiosas que ligan la imagen al cuerpo estaban basadas en una fuerte relación entre la mística y la plástica. María Morrás (2015, pp. 9-24) y Rebeca Sanmartín (2015, pp. 257-367) han comprobado, en las narraciones de otras visionarias, que la falta de educación escrita y una consiguiente afición más sensitiva o menos conceptual a las imágenes figurativas están relacionadas con un uso religioso tradicional de los sentidos corporales. Estos rasgos caracterizan los escritos de las místicas, y no sólo se trasponen en su semántica: su espontaneidad pocas veces anima los textos de los teólogos. Alison Weber recordó la expresión de Menéndez Pidal para definir la poesía teresiana, que "habla a través de la escritura" (2005, p. 77); Beatriz Ferrús se ha referido a este tipo de expresión de esta manera:

La imitación de Cristo y la meditación sobre su pasión y muerte, al modo ignaciano, serán una constante en las vidas de monjas, que encontrarán en la fisicidad y la humanidad del Hijo una forma de perforar el lenguaje teológico y dejar hablar a la mujer por medio de una corporalidad transformada en particular semiótica (Ferrús, 2008, p. 61).

Esa especie de comunión espontánea y corporal con una imagen se expresa en los textos de Ana a través de un lenguaje que algunos críticos han definido como rústico. Para Urkiza, el que la familia de la beata no fuese aristócrata y hubiese contratado a un clérigo para instruir a las hijas en el catecismo, así como el que Ana ejercitase la escritura como secretaria de Teresa, determina las cualidades de su grafía, las cuales sugieren cómo las imágenes le desvelaban los misterios: una "deficiente cultura inicial", "lengua vulgar del ambiente rural" $y$ "formas arcaicas anticuadas" con "decisiva influencia teresiana" e "influjos del francés" volcados en una prosa sin puntuación, con rasgos de automatismo (Urkiza, 1981, pp. 170-172; De Jesús Sacramentado, 1976, pp. 263-289). ${ }^{11}$

La Escena 10 de las estampas alemanas la representan como copista y secretaria de Teresa en el momento en que esta le cede la pluma en el convento de Salamanca, como Ana cuenta en la Autobiografía. ${ }^{12}$ El grabado omite algunos detalles respec-

10 Relaciones de conciencia (Pontoise, 1605) en Urkiza (1981, p. 127). Se ha escrito mucho desde la perspectiva de género acerca de las monjas modernas. Sobre estas experiencias en relación con la fe cristiana, ver Ditchfield y Smith (2017); sobre las formas de vida en los descalzos de mujeres y la relación de Teresa con Catalina de Cardona: Cruz (2016, pp. 246-265); para esta fase crítica en el gobierno de la orden: Atienza (2016, pp. 229-242); y un ejemplo de transmisión marginal de conocimientos en el caso de Ana: Mujica (2014, pp. 128-165).

11 Otros críticos de los textos epistolares de esta "mujer ayuna de cultura" la definieron como "clásica del todo": “y á pesar de los años que llevaba ausente de España cuando redactó la mayoría de estos documentos, no se halla en ellos sabor extranjero" (De Melgar y Abreu, 1917, p. 91).

12 "Estando un día la Madre en Salamanca (...) escribió dos renglones de su mano y dióselos [a Ana, que testifica] y a imitación de ellos escribió una carta esta testigo aquella tarde a las hermanas de San José de Ávila. Y desde aquel día las escribió y ayudó a responder las cartas que la Madre recibía, sin haber, como dicho tiene, tenido maestro ni aprendido a escribir de persona alguna, ni haberlo aprendido jamás, y sin saber leer más de un poco de romance, y con dificultad conocía las letras de cartas; por do conoce ser obra de Nuestro Señor para que ayudase a la Madre en 
to al dibujo preparatorio (fig. 2), como las armas de mortificación que cuelgan del muro. La representación promociona la historia y legitimidad del Descalzo como auspicio contrarreformista de una santidad capaz de infundir la ciencia, así como un argumento en defensa de las obras de Ana-escritora por milagro, transmisora de la doctrina espiritual y de la norma de comportamiento terrenal de las monjas, frente a sus detractores: sus interpretaciones de las Constituciones teresianas tenían que ser las buenas, si había aprendido a escribir de la voz letra de la madre. ${ }^{13}$

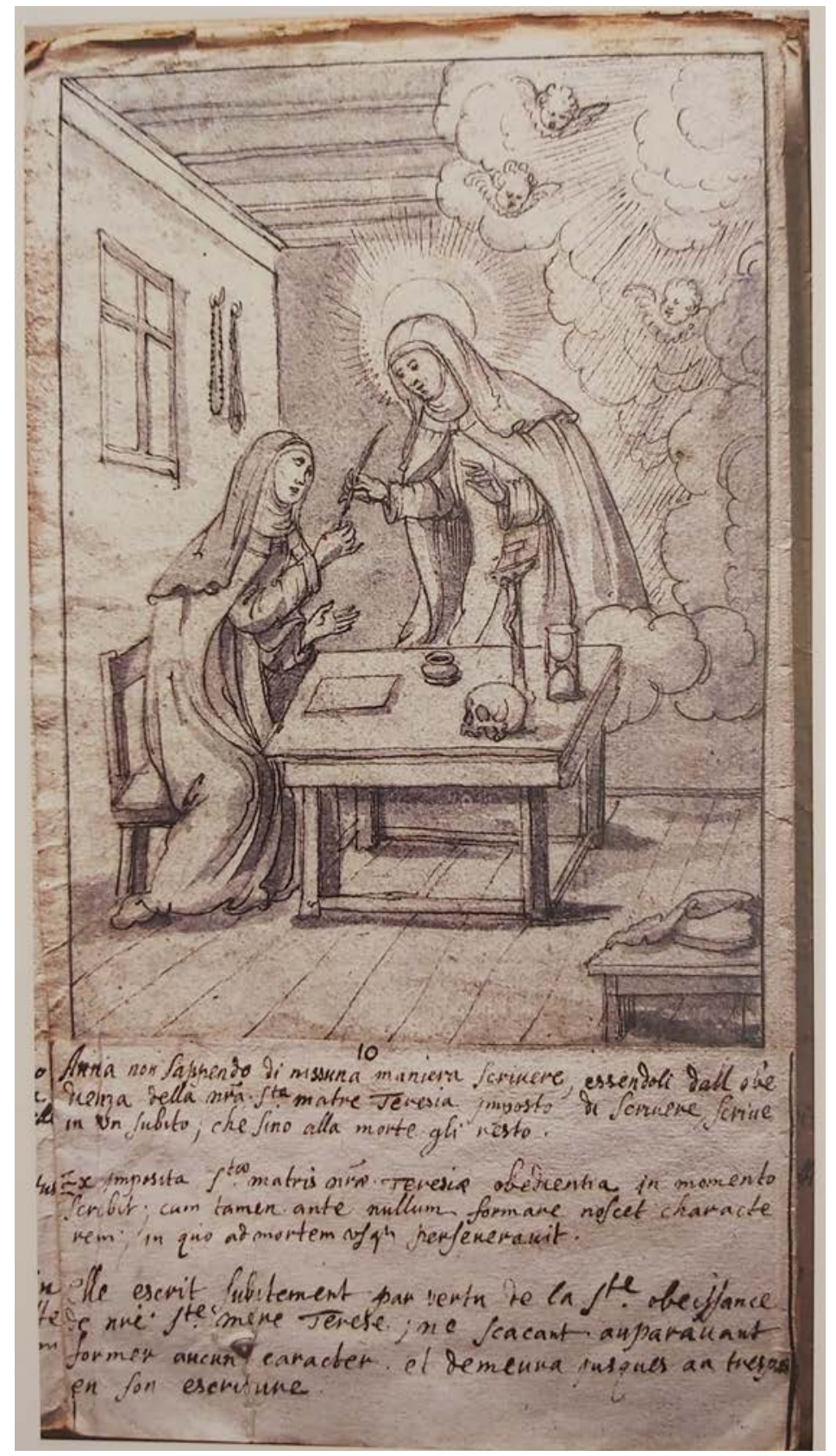

Figura 2. Anónimo. Dibujo preparatorio de la Escena 10 del Ciclo de la Vida de Ana de San Bartolomé. ¿Colonia, post quem 1637? Carmelitas de Amberes. [Fotografía: Ruiz y Urkiza, 2016, p. 62].

los trabajos y cuidados que por su amor pasaba con tanta alegría y regocijo". Procesos de beatificación y canonización de Santa Teresa de Jesús (Peña, 2012, p. 25).

13 Véase Ruiz y Urkiza (2016, pp. 62-63); los preparatorios de las estampas se conservan en el Carmelo de Amberes. 
Muerta Teresa, enviaron a Ana a Pontoise y convenientemente Dios le otorgó el don de lenguas para que pudiese cantar el breviario latino y hablar de las Constituciones en francés a las monjas. ${ }^{14}$ Según Leonor de San Bernardo, Cristo se ponía a su lado en los oficios, "la enseñaba a dezir y entender el latín mejor que si fuera romanze, aunque el entenderlo no durava siempre, sino algunas bezes, quando el Señor quería; el saberlo leer sí, mejor que muchas monjas del coro". ${ }^{15}$

Estas y otras declaraciones -a pesar de las estampas que representan a la beata como magistra noviciarum- apoyan la descripción que ella dejó de sí en la Autobiografía: "Pensando en mi poco ser y cosas de mi nada, hablóme el Señor y díjome: 'Ansí te quiero, sin ser ni saber nada, por açer por ti lo que yo quiero; que los sabios del mu[n] do con sus prudençias umanas no me escuchan, que piensan que lo saben todo'" (Autobiografía A, p. 340). Ella no se retrató como sabia sino como cuerpo sin formación que recibía las facultades de otros que actuaban a través de ella. Ferrús la denominó, por esto, "figura de ventriloquía" (2008, p. 67). Lo mismo sugirió Weber (2005). Como otras místicas, Ana practicaba una 'escritura por mandato', de "María, Josefe y Nuestra Santa Madre Teresa, en cuyo nombre hago esto, que me lo manda la santa obediençia". "Su grafía, con rasgos de automática, describe visiones infundidas por la divinidad y exalta una obediencia que la libraría de la autoría de sus obras; según el análisis del prólogo a las Recreaciones en el Carmelo que hizo Milagros Sánchez: "en él, no se pide ayuda a los destinatarios inmediatos como figuras totalmente externas e independientes del emisor. Como Santa Teresa en el prólogo al Libro de la vida, como San Agustín al inicio de las Confesiones, Ana acude a quien considera el autor de su discurso, que está dentro de él, pues lo inspira, y fuera, pues lo juzga" (1990, p. 934).

\section{Una vez vi en sueños}

Ana también decía que soñaba por mandato, al asegurar haber recibido, estando dormida, un conocimiento que adquiría empíricamente después de haber despertado. En la Autobiografía cuenta que, cuando llegó por primera vez a San José de Ávila, gracias a un sueño que había tenido antes, y que le ayudaron los clérigos a interpretar, pudo reconocer a las hermanas, las estancias, una jarra, cosas que, hasta entonces, no había visto con ojos corporales y racionales:

Soñé una manera de sueño que no sé cómo es, mas de que me parece que veía con los ojos un gran resplandor y en él una virgen muy hermosa que me mostró el monasterio de las carmelitas descalzas de Ávila con todas las celdas y monjas y las demás cosas que en él había, y me dijo que ella quería que fuese allí monja. Y luego vi a Nuestro Señor Jesucristo que me dijo lo mismo y me tiró con gran fuerza del rosario que yo tenía en la mano, con que me despertó. ${ }^{17}$

En ese relato, la autora elabora la imagen de un sueño que no sé cómo es a base de motivos de iconografía. Tras el gran resplandor, comparable al de las mandorlas y custodias solares, se conforma una virgen que presenta el suceso extraño y principal: la premonición, corroborada por la figura de Cristo, que consiste en ver la imagen del convento por anticipado. Las cosas que en él había son mostradas por esas figuras simbólicas que atraen la creencia; los iconos religiosos son umbral de imágenes proféticas: justifican

14 Compárese el Libro de la Vida de Teresa, cap. 15, con esta Relación de Conciencia redactada por Ana en Pontoise (1605) (Urkiza, 1981, pp. 119-127).

15 Apuntes y diálogos (Urkiza, 1981, pp. 209-210).

16 Prólogo de la Autobiografía A, p. 282. Ver Herpoel (1999) y Howe (2015, pp. 113-168).

17 Peregrinación de Anastasio, Diálogo Segundo (Peña, 2012, p. 12). 
la profesión de Ana, asignan esta misión terrenal al personaje, y la despiertan. ${ }^{18} \mathrm{El}$ desfase cronológico del hecho milagroso que se narra, respecto al acto de su narración, es notable: Ana relata el sueño siendo ya priora, es decir, habiendo cumplido la profecía. Las visiones auguraban su profesión como descalza que ya era cuando redactaba esas memorias, y se podrá sospechar que, en alguna medida, reelaboró esos sueños conforme a recuerdos, expectativas, técnicas de expresión que adquirió con posterioridad a esas noches visionarias (la certeza del origen histórico de la visión no afecta al efecto legitimador de su narración en la Autobiografía).

Otras visiones anticipatorias de la situación de la monja en el momento en que las relata predestinan su juventud y dan a su vida aspecto de historia con significado providencial: "Una vez vi en sueños, con tanta claridad y certidumbre como si estuviera despierta, muchos religiosos y religiosas desta Orden en Francia", escribió ya estando allí. ${ }^{19}$ Son confesiones de visiones "en despertando o medio dormida y como despierta" (Autobiografía A, p. 373) apoyadas en la tradición de sueños y vigilias que se usan como recurso en la literatura castellana medieval (Acebrón, 2004). ${ }^{20}$

\section{Y entendí en esto lo que decían}

Ese arreglo iconográfico de un pensamiento onírico, del que resulta una imagen que se percibe al bibo, como si estuviera despierta, puede observarse a distintos niveles en otro episodio imaginario, de madurez, donde Ana dice haber visto aparecer a Cristo Jardinero que la reclina en sus brazos para agradecerle sus trabajos de priora (Autobiografía A, pp. 312-316). Conscientemente o no, ella, en el ensueño, suple el papel de Magdalena en la historia de Juan Evangelista, 20, 15-17 y en las correspondientes iconografías del Noli me tangere. Pero Ana modifica esos modelos y, a diferencia de Magdalena, cumple su deseo en su historia, pues el Dueño del huerto no la huye ni le prohíbe tocarle, sino que la abraza, y eso la arrebata y beatifica. Las figuras de Magdalena y san Francisco en la iconografía cristiana son custodios del "estatuto del lugar" del pecador que espera redimirse y, en la Edad Media, se retrata junto a Cristo (Alcoy, 2017, p. 401). Como dijimos, Ana escribió haber jugado a ser Magdalena y, en esta visión del Hortelano, que tiene siendo priora, la iconografía canónica se adapta a su autobiografía para cederle el lugar de la Penitente; pero su relato no cita los versos del Evangelista, ni una máxima franciscana, sino palabras del Cántico Espiritual de Juan de la Cruz: Su visión "era en aquella graçia lo que diçe la esposa en los Cantares: Entrado se a la esposa en el verjel, entre los brazos de su amado, y a su sabor rreposa, el cuello rreclinado" (Autobiografía A, pp. 312-316). Los referentes predilectos de la institución teresiana empañan la cita al episodio bíblico y, en este sentido, la asociación del Carmelo y el hortus está cargada de significados (De la Pascua, 2019, pp. 35-65). Distintos referentes iconográficos modernos versionaban el Noli me tangere medieval: en conventos castellanos se conservan lienzos con escenas pastoriles del Divino hortelano al estilo sensual del óleo de Correggio. ${ }^{21}$

18 El Niño tira de su rosario en alguno de sus retratos, como en la Autobiografía B, pp. 129-230.

19 Diálogos sobre su espíritu (Urkiza, 1981, p. 199).

20 A partir de estos relatos se podría ahondar en la densidad del cruce de elementos iconológicos y psíquicos que conforman sus imágenes (ver Ramírez, 2002): “A los pensamientos oníricos latentes los llamamos también, a causa de su vínculo con la vida de vigilia, restos diurnos. Por obra del trabajo del sueño, al que sería por completo erróneo atribuir carácter 'creador', son condensados de manera extraordinaria, desfigurados por el desplazamiento de las intensidades psíquicas, arreglados con miras a la figuración en imágenes visuales, y además, antes de pasar a conformar el sueño manifiesto, sometidos a una elaboración secundaria que querría dar al nuevo producto algún sentido y alguna coherencia" (Freud, 1992, p. 237).

21 Ana aprendió de memoria poemas de Juan de la Cruz (los copió para las monjas) y dejó muchos ejemplos de cómo también la imaginería captaba sus afectos. Se postraba en el capítulo frente a un "Cristo atado a la coluna" hasta que quedaba "fuera de mí” y, como a Teresa, Él le hablaba: “'Mira cómo estoy tan [I]lagado y ligadas mis manos 
La contemplación repetida de estas imágenes y la repetición de versos alegóricos puede decantarse en la memoria y dejar restos diurnos que configuran pensamientos mediante un proceso onírico no inconsciente del todo -menos cuando son convertidos en historias-. Asimismo los dramas ofrecen estructuras narrativas y recursos argumentales a la expresión de estas experiencias: Patricia Garrido analizó un auto donde Cristo, disfrazado de Jardinero, hace creer a Magdalena que es su pretendiente: una dramatización moderna del Noli me tangere basada en la acción argumental del reconocimiento, que, según el estudio de Garrido, fue muy representada a partir de la segunda mitad del siglo XVI, cuando el teatro estaba revalorando la anagnórisis - cosa que, a Ana, le ocurría muy a menudo: casi a cada visión que tenía, reconocía el significado oculto de algo-. En esos autos -observó Garrido- los desvelamientos de identidad oculta en figuras indirectas suelen producirse ex machina (1999, pp. 102-108) e, igualmente, el desvelamiento de figuras simbólicas que intervienen milagrosamente en la historia de Ana para explicarla, y corresponden a tipos de iconografía, suelen resolverse sin interpretaciones complicadas. La resolución del misterio de la visión podía ampararse en la historia 'verdadera' que narraba la pintura, la poesía, el teatro, los teóricos carmelitas y los consejos beatíficos de los Padres: "no vemos a Dios con los ojos del cuerpo, como vemos los cuerpos celestes o terrestres, ni tampoco con la mirada de la mente, como esas cosas que ves con certidumbre dentro de ti misma". ${ }^{22}$

Aunque las monjas no competían en autoridad frente al discurso teológico, se supone que, en la clausura, podían rendirse a sus visiones "sin preocuparse de una posible explicación teórica de su experiencia, sin preocuparse tampoco del juicio o censura que su explicación pudiera merecer" (Stein, 1994, p. 204). Pero las monjas estaban obligadas a pasar sus experiencias por un filtro terapéutico de narrativa en estas autobiografías por mandato, o en el testimonio que dirigían a sus confesores. ${ }^{23}$ En el caso de Ana, hay que añadir el factor de la dificultad que, según escribe, le supone en Francia el idioma vernáculo, y el tener como interlocutor a su confesor, el cardenal Berúlle; en las cartas por mandato que le dedica, se excusa de no poder explicarse: "algunas cosas sobrenaturales son dificultosas de escribirse ni saberlas poner nombre, porque mi entendimiento es muy corto, y crea vmd. que no es por no lo querer haçer, que deseo obedeçer más de lo que vmd. piensa". ${ }^{24}$

A veces Ana explicita las fuentes de las citas que autorizan sus visiones y aclara la correspondencia de lo que ve con los motivos canónicos, por ejemplo, en París, cuando, según ella, se siente despreciada por quienes traicionan los principios teresianos: se le aparece "otra diferençia de cruz", un lienzo lleno de "crucecitas, que fue a la traça de quando mostraron a S. Pedro una sábana llena de unas savandijas pequeñas". ${ }^{25}$ El ejemplo bíblico autoriza el símil del atributo de los religiosos y las alimañas que

por ti, así te quiero yo io, como a mi amiga'. Antes y después siempre que entro delante de este Cristo, parezen se amortiguan mis penas. Está muy llagado y ligadas las manos, que es cuando le acavaron de dar los azotes, está muy al bibo esta pintura" (Relaciones de su estancia en París [1607], Urkiza, 1981, p. 157). Otras veces es una escultura, y repite la fórmula teresiana: “Avía un Cristo en el Capítulo, de piedra, grande y muy ligado. Yo le tenía mucha devoción (...) y le pidía me diese buenos pensamientos por sus llagas (...) Y en esta afliçón me abló este Cristo y me dijo, mostrándome su agonía, que venía atadas las manos como cuando le desatavan de la coluna después de coronado de espinas y desnudo sentado sobre una piedra, y llegóse a mí. Díjome con mucha dulçura: 'Yja, mírame cual estoy, y por ti, atado y ligadas mis manos, y cómo estoy esperando agan de mí lo que quijeren'. Y díjome: ‘Ansí te quiero como amiga'" (Autobiografía A, pp. 347-348).

22 Carta de Agustín de Hipona a Paulina (147) traducida por Cilleruelo. Sobre esta influencia en la mística teresiana, ver Lahoz (2015).

23 En el Libro de la vida (1565, 29, p. 5) un confesor ordena a Teresa 'dar la higa' a Cristo cada vez que se le aparece, suponiendo que es un demonio. Ello recuerda al uso que hace un psicoanalista de los símbolos del sueño como “figuras sin gramática”, “de un infinitivo extremado", imágenes que encriptan un objeto de deseo y a las que, por tanto, él, y no el paciente, atribuye significado reintegrador (Freud, 1992, p. 202).

24 Relaciones de su estancia en París en Urkiza (1981, p. 133).

25 Relaciones de su estancia en París en Urkiza (1981, p. 149). Cf. Hechos 10, 11-13: “Y vió el cielo abierto, y que descendía un vaso, como un gran lienzo, que atado de los cuatro cabos era bajado á la tierra; en el cual había de todos los animales cuadrúpedos de la tierra, y reptiles, y aves del cielo. Y le vino una voz: Levántate, Pedro, mata y come”. 
Pedro como Ana se habían de comer, metafóricamente, en su misión (fig. 3). Pero generalmente ella prefiere mostrar que no conoce la fuente de la cita que menciona, o que le es desvelada en la visión, como aquí:

Acabando de comulgar (...) vi a mis dos lados cuatro animales blancos como corderos, postradas las bocas en tierra, que adoravan a Dios que yo avía rreçibido. Y oý una boz que me deçía: 'Semejante a éstos es tu rreverencia'. Y entendí en esto que deçían: 'Estos son los cuatro animales del profeta Eçequiel, del Apocalis' (Autobiografía A, p. 317).

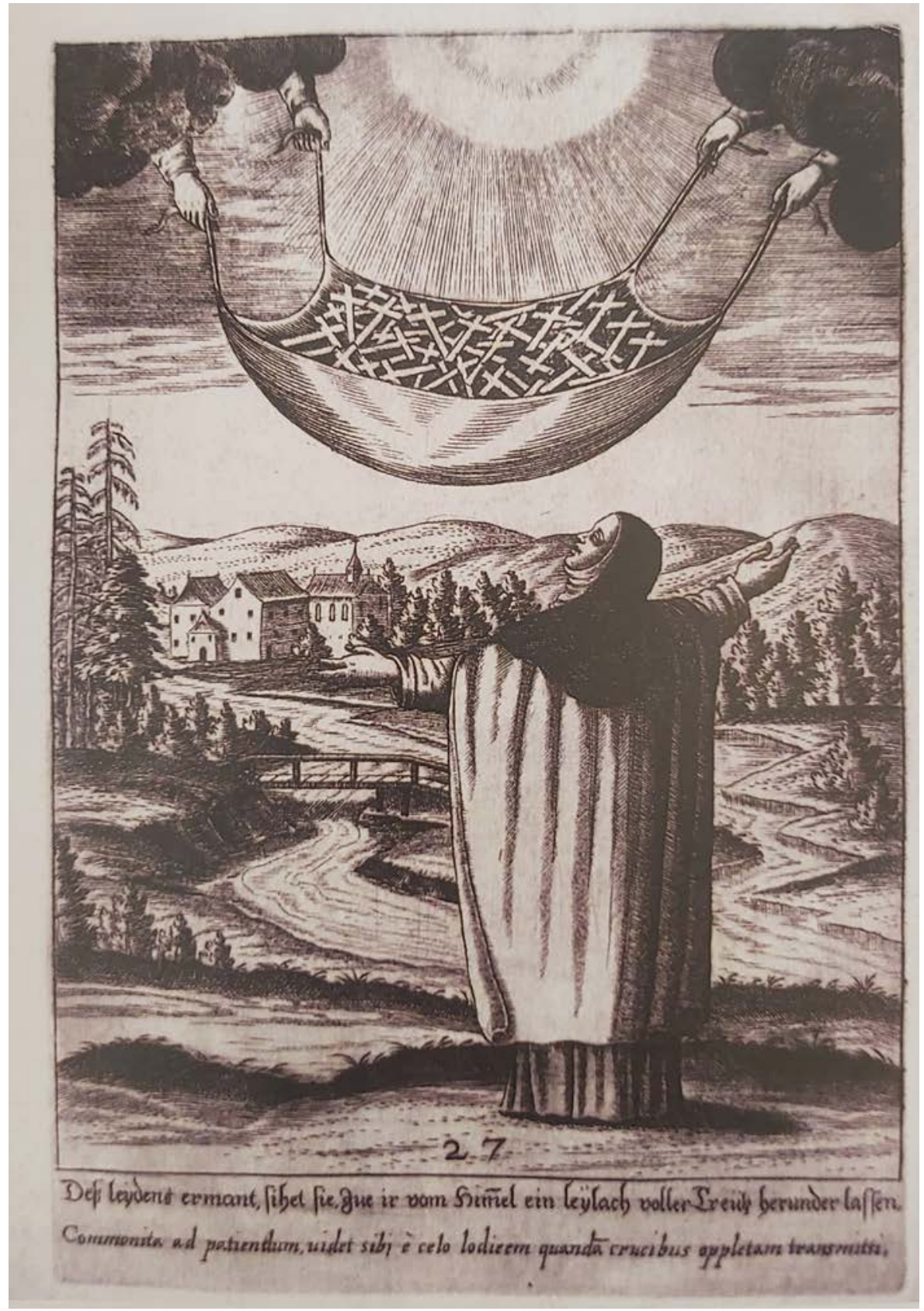

Figura 3. Anónimo. Estampa. Escena 27 del Ciclo de la Vida de Ana de San Bartolomé. ¿Colonia, post quem 1637? Carmelitas de Munich. [Fotografía: Ruiz y Urkiza, 2016, p. 97]. 
Se supone que la monja no reconoce el símbolo que describe hasta que se le desvela en la locución que acompaña a esta visión; pero al menos ella tenía que haber servido en la liturgia de los conventos donde profesaba y había recibido la catequesis que enseña la relación figural del Cordero y la Eucaristía. La locución explica esa asociación visual de Viejo y Nuevo Testamento, y así fue grabado en la Escena 26 del ciclo de estampas (fig. 4) para publicitar un argumento contrarreformista a favor de sacramentos rechazados por los protestantes (Ruiz y Urkiza, 2016, pp. 94-95) si bien Ana incide en el rrecogimiento y rreverencia que le provoca esta imagen, más que en el razonamiento teológico que infunden las diferençias de figuras bíblicas:

Un día, me acaeció oír un sermón de la pasión a un predicador y pareciéndome que no había declarado los dolores de Cristo como ellos eran, sino deteniéndose en no sé qué de teologías, salíllorando con muchas lágrimas, y preguntándome mis hermanas por qué lloraba, les dije que porque aquel predicador no había sabido predicar. ${ }^{26}$

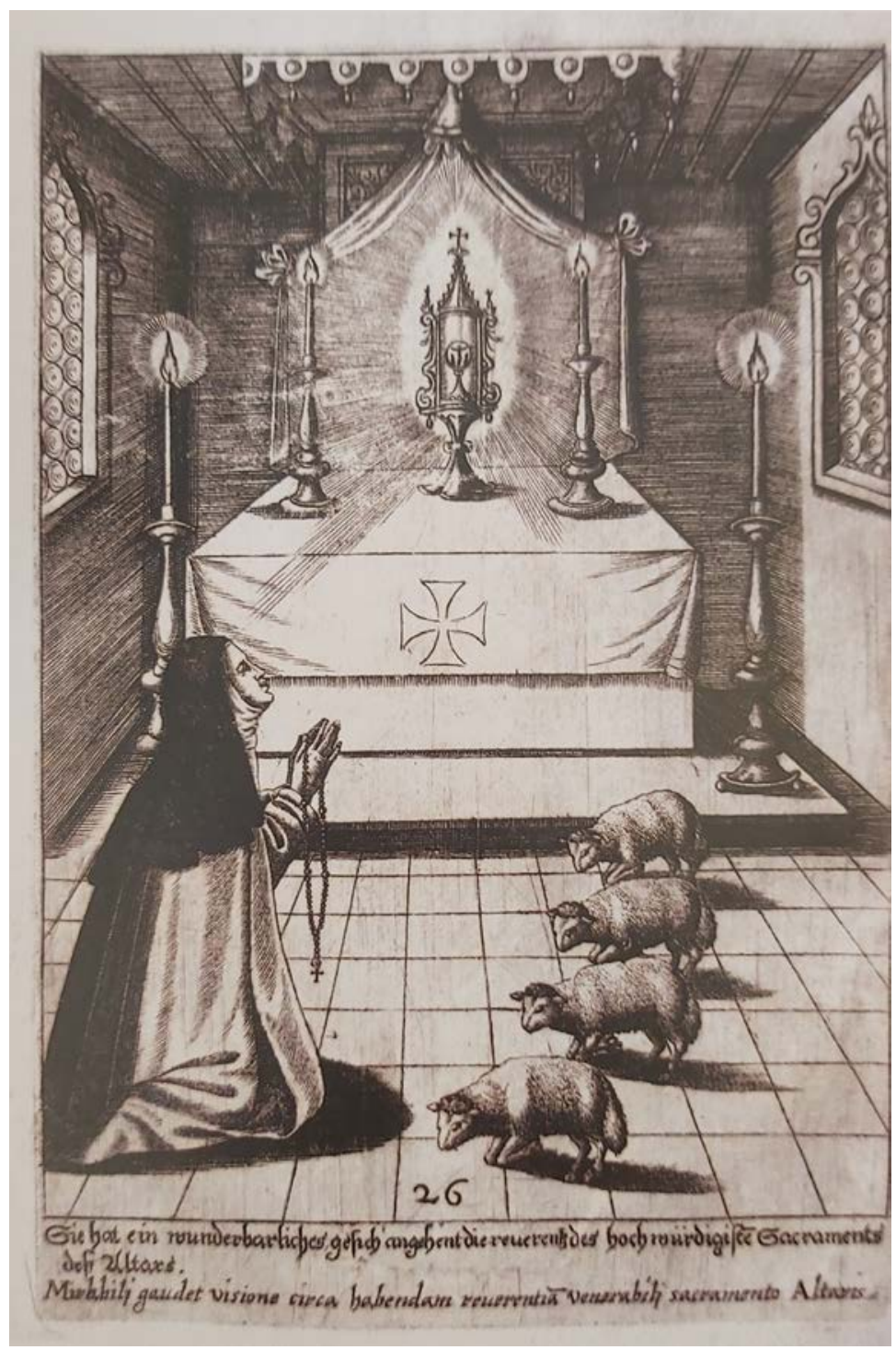

Figura 4. Anónimo. Estampa. Escena 26 del Ciclo de la Vida de Ana de San Bartolomé. ¿Colonia, post quem 1637? Carmelitas de Munich. [Fotografía: Ruiz y Urkiza, 2016, p. 95]. 
No importan las razones de la Pasión tanto como los afectos de imágenes que se usan como "medio de conmoción activa y somática" para entender y, en última instancia, trascender la imagen con 'ojos del corazón' agustinianos.

\section{Las facciones de su rostro eran pintadas}

El soporte más palpable de estas visiones son iconografías del "drama de Cristo" instaladas en cuerpos plásticos que exigen "participación" a las fieles, primero "dando fe de lo que ven" (la divinidad encarnada) y luego "imitándola" para convertirse, a su vez, en ejemplos vivos a imagen de la imaginería (Lahoz, 2015; Belting, 2011). En palabras de Portús, el retrato conventual es "un asunto fundamental para entender la transmisión de la información iconográfica en la historia del cristianismo, como es el proceso de formación de un vocabulario formal que adjudicaba a cada personaje o escena unas convenciones de representación con aspiraciones arquetípicas y muy codificadas" (Portús, 1999, pp. 169-188). ${ }^{27}$ Como ha expuesto Belting, la corporeidad de lo invisible era precepto de los primeros cristianos y uno de los temas preferidos de los debates de la iconoclastia: el cristianismo se basa en que Dios se encarnó en el Hijo, vera effigie de Hombre que se grava en la memoria de los fieles, hechos también a imagen de la divinidad. Ana dice que, desde pequeña Lo veía, "de donde hasta ahora me queda impresa aquella figura y rostro de Cristo con grandes deseos de amarle". ${ }^{28}$ En los poemas que le atribuyen, se plasma la imagen que invoca para la ascesis: "¡Dios mío y mi Señor! Tened memoria, que ha visto ya mi fe vuestra figura y que sin ella no ay para mí gloria...". ${ }^{29}$ Edith Stein insistía en lo conservador de estas tendencias modernas: "en el Antiguo Testamento estaba permitido, en conformidad con la ordenación divina, desear visiones y revelaciones y dejarse guiar por ellas, porque Dios descubría de esta forma los secretos de fe y manifestaba su voluntad" (1994, p. 85). Y Lahoz ha puesto de relieve que la fijación de Teresa en la figura humana de lo divino es anterior respecto a los episodios de iconoclastia protestante y la exaltación oficial de la iconofilia católica. No obstante, las técnicas que expresaban el debate medieval de la relación de la imagen ontológica y la representada, la reconciliación de las nociones de máscara y persona, cambiaron: la imprenta multiplicaba nuevos rostros de santidad como espejo de almas triunfantes (Belting, 2011, p. 183).

También se multiplicaron las autobiografías. Ana se retrataba en la suya, a imagen de los ejemplos que había imitado en sus años de 'formación', no sólo intelectual, y daba significado así también a su aspecto físico, calco del prototipo en su entorno. El ideal de las comunidades donde ella ascendía de estatus era vivir o morir como santa y, con ello -ha notado Portús- tener cara de santa (Portús, 1999). ${ }^{30}$ Un arte retratístico formulario estimulaba la imitatio como especie de mímesis invertida. ${ }^{31}$ Las descripciones de la fisionomía de Ana caen en la imitación del modelo artístico al mencionar sus "ojos vivos", su "cara llena de magestad", 32 el "agrado exterior de su rostro, que era manifiesto indicio del sosiego y quietud de que gozaba su alma", dice el P. Enríquez y lo recoge Florencio del Niño Jesús, quien jerarquizó

27 Véase también Portús (2011, p. 37-47) sobre los usos de las imágenes en el arte barroco hispánico.

28 Peregrinación de Anastasio, Diálogo primero (Peña, 2012, pp. 8-9).

29 Suspira el alma por ver a Dios. Poesía de Ana de San Bartolomé según Urkiza (1981, p. 707), aún atribuida con dudas a Juan de la Cruz, desde recopilaciones como la de De San Juan de la Cruz (1914, p. 197).

30 Ana de San Bartolomé sobre María del Sacramento: “murió como santa y quedó como ángel después de muerta, y su rostro parecía un cristal (...) tratable como si estuviese biba”, en Urkiza (1981, p. 111).

31 Aunque ya "en la consideración iconográfica del retrato, el retratado viene a erigirse en alegoría de sí mismo" (Moralejo, 2004, p. 16)

32 Fragmento de la declaración de Clara de la Cruz en el Proceso de beatificación, en Peña (2012, p. 98). 
los tópicos en los estudios fisionómicos y biográficos sobre Ana, rematando su écfrasis de esta manera: "su verdadero retrato, en fin, es el de una perfecta hija de Santa Teresa" (Del Niño Jesús, 1917, pp. 36 y 272). La prima de Ana, Francisca, dejó la descripción más concreta que suele citarse y es metáfora de un rostro pintado, un cara-retrato: "Era de muy lindo cuerpo, de mediana estatura; las facciones de su rostro eran pintadas, que aunque todos sus hermanos y hermanas eran de buen parecer, ella les llevaba la ventaja en hermosura".33

Pero ella no adquirió su derecho a figurar en los ciclos hagiográficos gracias a una belleza innata, sino tras superar su calvario formativo en el 'camino de la cruz' que recorría en paralelo al drama de Cristo. Él es el 'verdadero ejemplo' que ofrecía el espejo del arte en su Autobiografía. "Siendo niña de cinco años, me parecía traerle cabe mí de la misma edad que yo era, con un rostro y unos cabellos largos". 34 Cuentan que solía decirle a sus novicias:

Que si pudiera pintar, pintaría al pequeño Jesús en la misma forma en que se le aparecía en su niñez, y añadía que era muy hermoso, de pelo rizado sobre los hombros, de color castaño, con un vestido morado, como los nazarenos, con unos ojos resplandecientes y ardientes, tan atractivos que no se atrevía a mirarlos fijamente, pensando que, si los miraba, moriría de amor. ${ }^{35}$

El deseo de representar esa aparición-espejo a la pequeña pastora fue cumplido en la Escena 2 del ciclo alemán (fig. 5), que convierte el campo toledano en un paisaje noreuropeo (Ruiz y Urkiza, 2016, p. 46). Las visiones acompañan a la beata en los ritos de pasaje a la madurez, devolviéndole la apariencia adulta de Cristo en la Pasión, pues Él es la imagen que ella dice ser reflejo de la suya, la cual modela, a su vez, conforme a los prototipos del arte religioso. Es precisamente al cabo del año de noviciado cuando, en la ermita del convento de Ávila "aparecióseme el Señor en la cruz (...) y díjome: 'Mi sed no fue sino de almas, ya es menester que mires en esto y vayas por otro camino que hasta aquí. Como si me dijera: 'No me busques más Niño"' (Autobiografia A, p. 292).

33 Relación de Francisca Cano sobre la infancia y juventud de Ana de San Bartolomé, en Urkiza (1981, p. 782).

34 Peregrinación de Anastasio, fragmento del Diálogo primero, en Peña (2012, p. 8).

35 Clara de la Cruz en el Proceso de beatificación de Ana de San Bartolomé, en Peña (2012, p. 11). 


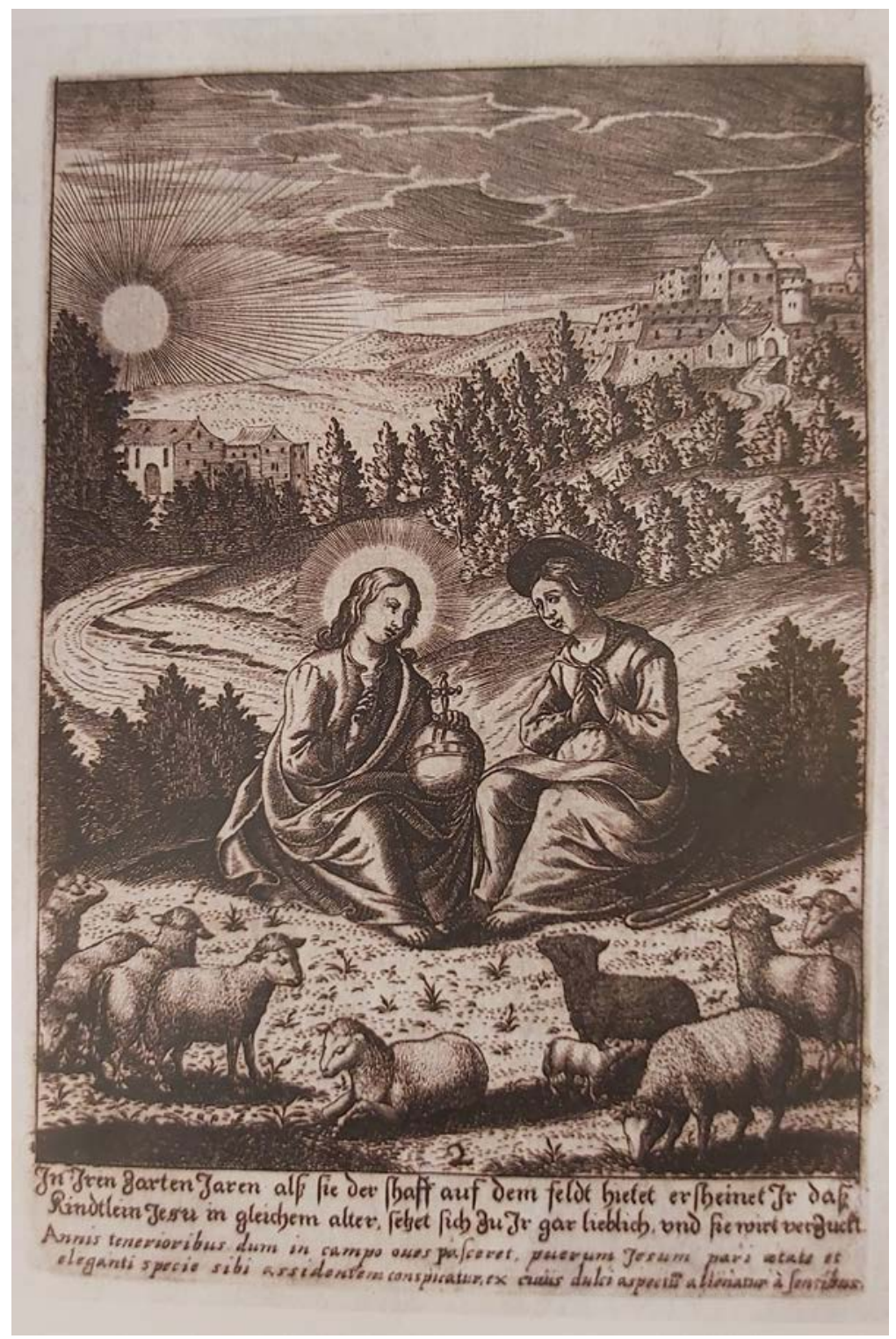

Figura 5. Anónimo. Estampa. Escena 2 del Ciclo de la Vida de Ana de San Bartolomé. ¿Colonia, post quem 1637? Carmelitas de Munich. [Fotografía: Ruiz y Urkiza, 2016, p. 47].

La progresiva configuración de la imagen de Ana va marcada en su historia por otro cambio de registro visual. Ella fue freila de velo blanco, y este color la identificaba en el Carmelo, pero cuando la eligen para fundar en Francia (1604) le exigen la renuncia del vestido que tanto significa. Ya priora recuerda esta imposición como rito de paso que supera gracias a las visiones de Cristo y de Teresa: la empujan a acatar el negro en 1605 y la consuelan. El cambio cromático es señal que anticipa el cumplimiento de la misión, y así, vestida de negro, pasa a la siguiente estación en la Autobiografía: el priorato de París, su 'noche oscura'. En ese periodo de enfrentamiento con Bérulle, escribió poesías a su "caríssimo amado, no me dejéis en tribulaçión". ${ }^{36}$ Más adelante, en el relato, supera este calvario y se yergue Libertadora en Amberes. Así, su imagen, consolidada en una historia heroica, se utilizó como arma de retaguardia contrarreformista en Flandes. 
Portús ha analizado las funciones del retrato conventual del Siglo de Oro: "instrumento fundamental de religión" que "jugaba un papel específico entre los medios iconográficos, que permitían actualizar la memoria histórica del catolicismo", y una de las contrarreformas consistía en "mostrar ejemplos vivos o recientemente fallecidos de héroes contemporáneos", con la consiguiente "inflacción" de santos en la carrera genealógica entre comunidades religiosas e individuos que produjeron infinidad de historias y autobiografías fieles al patrón (Portús, 1999, p. 170). La representación naturalista del rostro de la beata, en este contexto, era un "acto de fe" en el poder de la imagen, lo mismo que pudo serlo, a finales de la Edad Media, el representar la Creación y sus criaturas; aquí, "la semejanza con Cristo no es, pues, un acto de presunción; es, al revés, una actitud de humildad". ${ }^{37}$ La relación especular que Ana dice guardar con Aquél, en su pasión como en su fisionomía, es decorosa en tanto el código de la Fama del Siglo de Oro permitiese la "relación paradójica" que -en términos de Portús- vincula "retrato y humildad". La obra escrita de Ana participa del fenómeno creciente de la autobiografía por mandato, parejo al del retrato conventual, y es tal que, algunas escritoras, como ella, han sido diagnosticadas de "ansiedad de autoría". Esto suele justificarse por la comentada marginación de las mujeres en la educación letrada y porque, aun queriendo destacar en la cultura, buscaban "humildad" en su imitación, en su com-passio, y no caer en la vanidad (Weber, 2005, p. 79).

Ana escribe sobre sí misma, quizás, para legitimarse cuando la "desprezian públicamente". ${ }^{38}$ Pero no defendía la autoría personal de sus escritos, sino que exaltaba esa actuación transmisora como virtud de humildad -insiste Weber-. Se mostraba como recipiente para la encarnación de una imagen que aseguraba sentir bajo muchas formas y que la traspasaba. Sus obras cumplían mandatos que recibía de la efigie de Cristo, de una madre Teresa que le enseñara a hablar y escribir por ella, de una escultura, del olor de una reliquia, una voz que se introdujera en su cuerpo, no siendo ya propio, y actuara también a través de sus retratos, y luego de sus reliquias, como por contagio. 39

Ana describió visiones donde Cristo le ofrecía su corazón hasta arrebatarla, se lo intercambiaba, se lo estrujaba o traspasaba, como a Teresa o santa Lutgarda. El siguiente extracto se refiere a una pintura que desconozco, pero cuya descripción combina el motivo de estas descripciones -Cristo abre su corazón a la monja en la Escena 31 del ciclo (fig. 6)- con el abrazo del citado sueño del Hortelano:

La señora María Enríquez deseaba tener un retrato de la Madre Ana y un día la misma Madre le dijo: "Ven a la sacristía, y allí te daré", no añadiendo qué. Y la misma deponente fue a la sacristía, y habiendo allí un torno, la venerable Madre le dio por el torno a ella cierta tela envuelta, diciéndole: "Toma, hija mía, te pido que no lo muestres a nadie ni digas nada a nadie". Y la misma deponente, viendo que allí no había nadie, volvió a su casa, y al desenvolver dicha tela, que era de una altura de dos codos, y medio codo de ancho, vio pintada a la Madre, de rodillas ante Nuestro Salvador que le ofrecía su corazón, y Nuestro Salvador pintado estaba al lado derecho de la venerable Madre Ana con una capa roja, y la mano derecha puesta sobre el hombro de la venerable Madre Ana, y la otra mano puesta a manera de hablar a la Madre. Y cuando la deponente vio esa imagen o efigie se alegró muchísimo. Y al día siguiente se fue donde la Madre Ana para darle gracias. Y entonces ella le dijo a la deponente que la guardara en un lugar secreto y se lo dijera a su marido, pues la misma deponente había pedido muchas veces a la Madre para que se

37 Belting ante el "icono en el Autorretrato de Durero" (2011, p. 126).

38 Carta de la princesa de Longabila a Ana de Jesús, advirtiendo de la situación de la beata en Francia, en Ana de San Bartolomé, en Relaciones de Conciencia (Urkiza, 1981, p. 150).

39 Mímesis por contacto que difiere de las categorías aristotélicas del arte (López de Munain, 2018). 
dignara interceder ante Dios por la salvación del alma de su marido, y que rezara un padrenuestro y avemaría a Nuestro Salvador que estaba pintado en la imagen; y el mismo día, hablando la deponente con la hermana Clara de la Cruz y con dos o tres monjas más que estaban en el locutorio con ella, declaró la alegría que sintió al tener dicha imagen. ${ }^{40}$

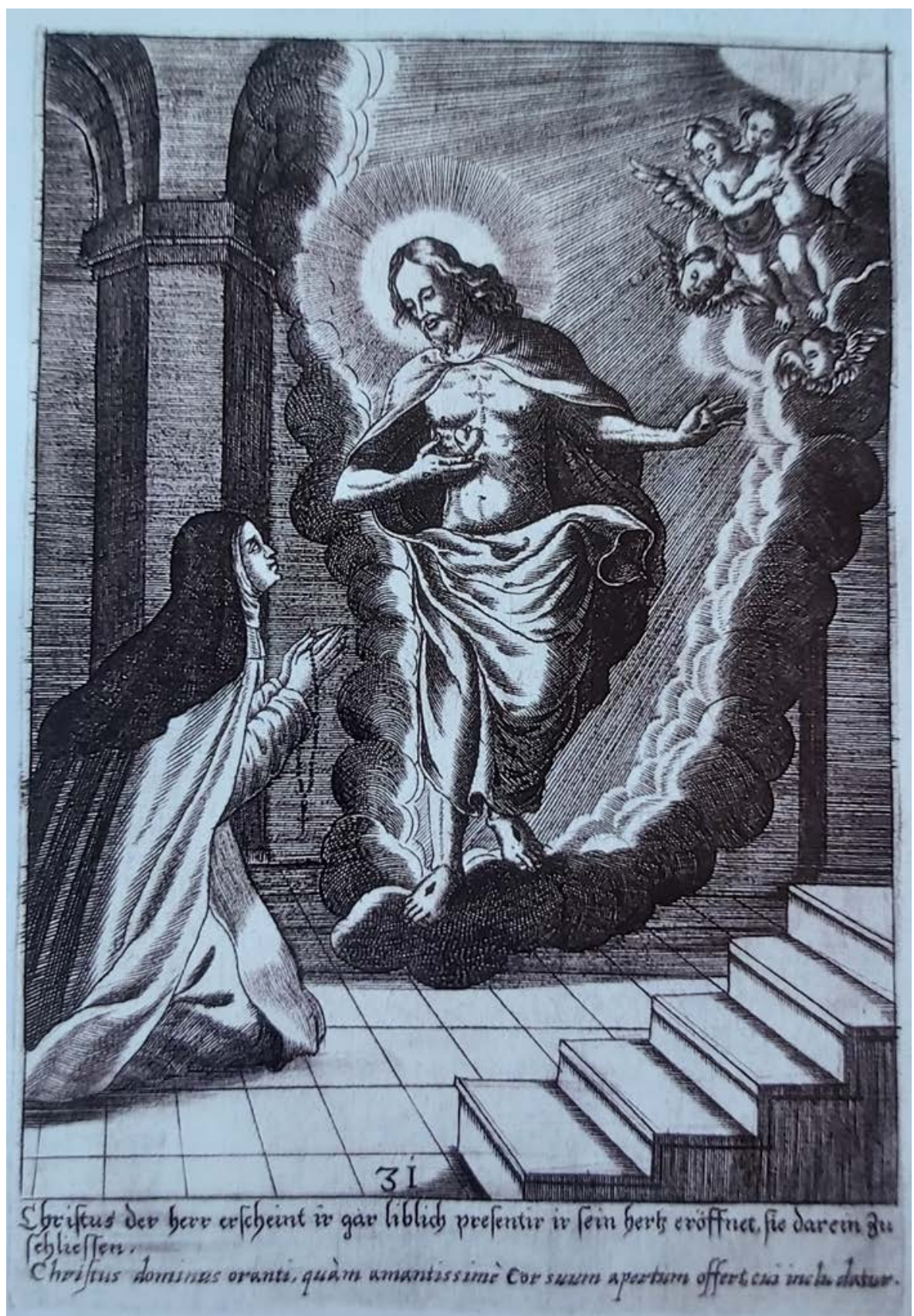

Figura 6. Anónimo. Estampa. Escena 31 del Ciclo de la Vida de Ana de San Bartolomé. ¿Colonia, post quem 1637? Carmelitas de Munich. [Fotografía: Ruiz y Urkiza, 2016, p. 105]. 
Portús ha notado que la pintura conduce a un "clímax emocional más afectivo" gracias a la "iconografía", y, en los escritos de Teresa, Lahoz ha percibido esta función emotiva concentrada en el "elemento plástico": por tanto, la mayor capacidad de la escultura frente a la pintura, a la hora de transmitir una sensación corpórea. Según Portús, el concepto que la mayoría culta tenía de la "originalidad e historicidad" en el Siglo de Oro permitía considerar una imagen más verdadera cuanto más cercana física y fisionómicamente era a la efigie original. La jerarquía de las reliquias era primero anatómica y luego regida por el tipo de contacto que el objeto hubiese tenido con el cuerpo sacro: una consideración plástica del objeto y del valor taumatúrgico de lo que transmiten los sentidos corporales, ligada a una fuerte relación entre retrato y 'viveza', en términos de Portús, o imagen y cuerpo (Belting, 2012). El retrato mui bibo que describe Ana podía tener cualidad de reliquia y ser medio de visión mística, pues la obra de arte cumple esa "función sustitutoria" del cuerpo como ejemplo al nivel de la memoria, de las creencias y de las tradiciones, a través de lo "pintado en la imagen" (Portús, 1999, pp. 174-175).

\section{La verdadera imagen}

Se podrán reconocer hasta aquí muchos rasgos de la virtual 'teoría de la imagen teresiana' delineada por Lahoz a través de los textos de la santa, que manifiestan su "concomitancia con la tradición mística imaginativa y figurativa tardomedieval". Están empapados de una cultura iconófila que valora la función cultual y las "unciones evocativas del retrato" por encima de las cualidades estéticas y técnicas; el predominio de la escultura como medio duradero que representa en tres dimensiones el drama de Cristo no menoscaba el consumo de obras gráficas de mercado que perpetúan las devociones de rostros obsolescentes (Lahoz, 2015). ${ }^{41}$

Ana se escribió a sí una imagen duradera de transmisora de la 'verdadera imagen', y de este modo se posicionó en el entorno de Isabel Clara Eugenia y los militares en Amberes, a quienes daba bendiciones y estanpas: remedios contra la enfermedad, la guerra y las herejías. Durante los cercos protestantes de 1622 y 1624 sus rezos se promocionaron como protectores de la ciudad y fue nombrada públicamente Libertadora. Con ese rol aparece en grabados y lienzos que evidencian la influencia teresiana, lo mismo que sus visiones, devociones y biografía. ${ }^{42}$

Las inscripciones de uno de los grabados más reproducidos y versionados identifican a Ana van den S. Bartholomeus arrodillada ante el crucificado de bulto que reposa sobre un libro elocuentemente cerrado en un interior conventual austero, abierto al puerto y la ciudad cercada de Antwerpen. Ana no mira a la escultura sobre el libro sino al haz de rayos que baja del cielo a sus manos orantes y le arenga con una locución en pro de la victoria bélica, política y religiosa: Ora magis magis magis. De esta estampa, impresa hacia 1626 , se conocen versiones que traducen al castellano las inscripciones: "La venerable madre Ana de S. Bartolomé. Ruega más más más" (fig. 7). Este Verdadero retrato combativo podía recortarse hasta dejar su medio cuerpo aislado en detrimento de la narración histórica, acaso conocida por otros medios, o recordada por escrito en la estampa, potenciando a cambio los estímulos a la devoción de un busto naturalista enmarcado. La beata, en los óvalos, mira al crucifijo que sigue sobre la mesa, junto o

41 Stein mantenía principios filosóficos que conllevan esta manera de fruición artística, explicada por Juan de la Cruz en la citada Subida al Carmelo (1994).

42 Los retratos de carmelitas solían estar costeados por la orden y pintados por religiosos. El prototipo de Teresa fue determinante (Juan de la Miseria, Jan Narduck, 1576). 
sobre el libro cerrado. ${ }^{43}$ Las copias del siglo XVIII añaden inscripciones que recuerdan a la heredera de Teresa, beata por sus milagros. Franz de Wilde hacia 1917 viró ligeramente el punto de vista de la composición y destinó la superficie de la mesa a ampliar la inscripción de una historia ya remota.

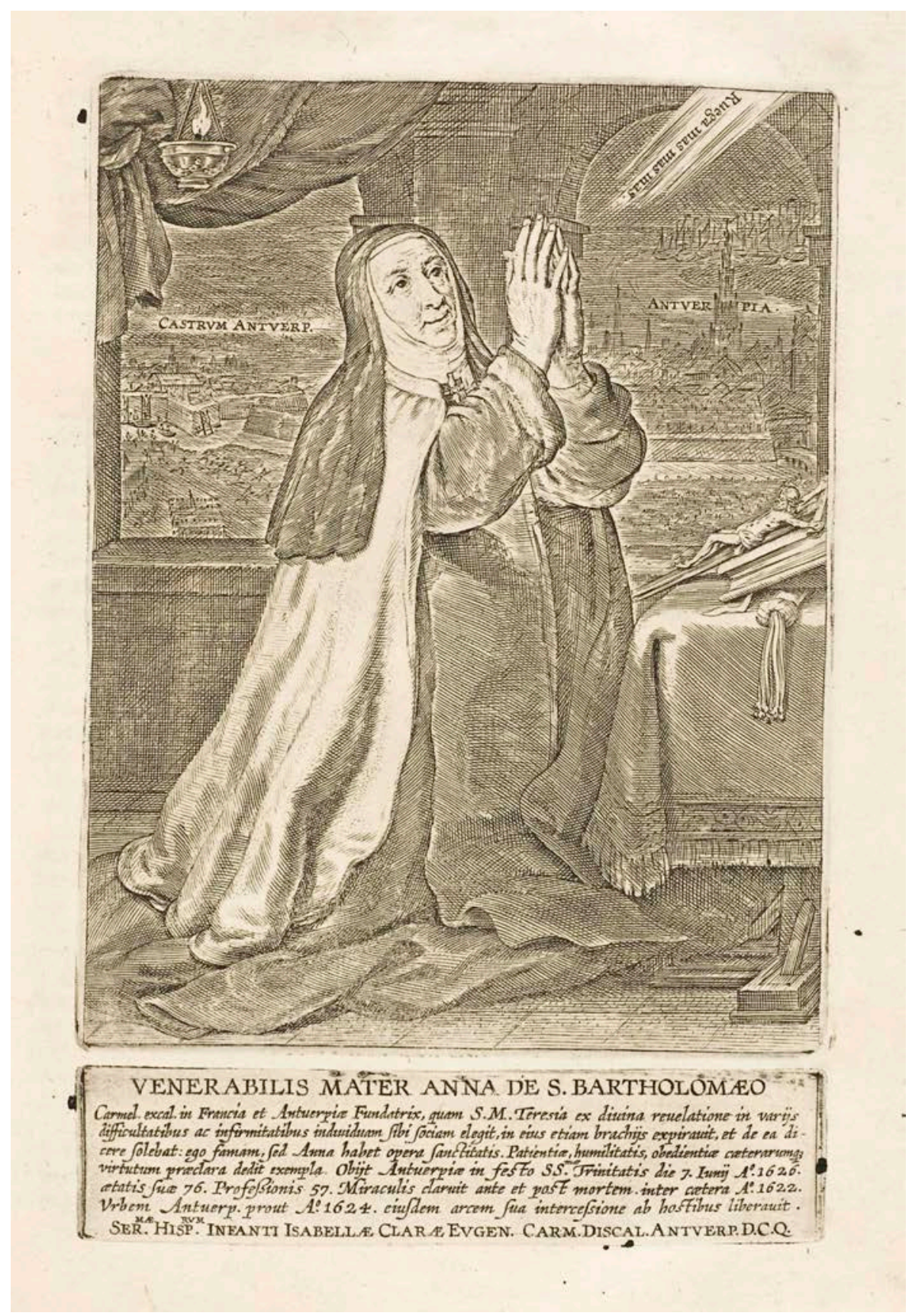

Figura 7. Anónimo. Estampa. Retrato de Ana de San Bartolomé. Bruselas, 1739 (copia del grabado anónimo La venerable madre Ana de S. Bartholome dedicado a Isabel Clara Eugenia por las descalzas de Amberes, 1626). Biblioteca Nacional de España, ER/440 (64). [Fotografía: BNE].

43 Una de Cornelis Galle el Viejo hacia 1626; otra, más ornamentada, de Jan Veroheven, de 1637; otra de Michiel Cabbacy y Johannes van de Sande, después de 1675, que incluye la fecha de muerte: 7 de junio de 1626. Casi todas las estampas mencionadas en este ensayo se conservan en la Biblioteca de la Universidad de Amberes, que las ha digitalizado en su plataforma. El resto, cuando se indica, corresponden al ciclo de estampas catalogadas en Ruiz y Urkiza (2016). 


\section{¿Es posible, Señor, que os quiere ansí vuestra esposa?}

Se puede aplicar lo dicho comparando un manuscrito vinculado a Ana (Contemplación que transcribió Matías del Niño Jesús en 1944) con este Berdadero retrato en lienzo (fig. 8) que traspone el modelo de las estampas (Muñoz, 2018). Sendos soportes -la escritura de las contemplaciones y el retrato escrito y pintado de la contempladora- comparten esa función sustitutiva de lo contemplado: la divinidad encarnada. La manuscritura comparte el valor de autenticidad de la reliquia y de la 'verdadera imagen', precedida de la verificación de Juan de la Madre de Dios (1648): "la conozco y confieso ser toda de la propia mano de Nuestra Venerable Madre Ana de San Bartolomé, la cual se debe estimar y venerar por grande reliquia" (Del Niño Jesús, 1944, pp. 79-87, passim). ${ }^{44}$

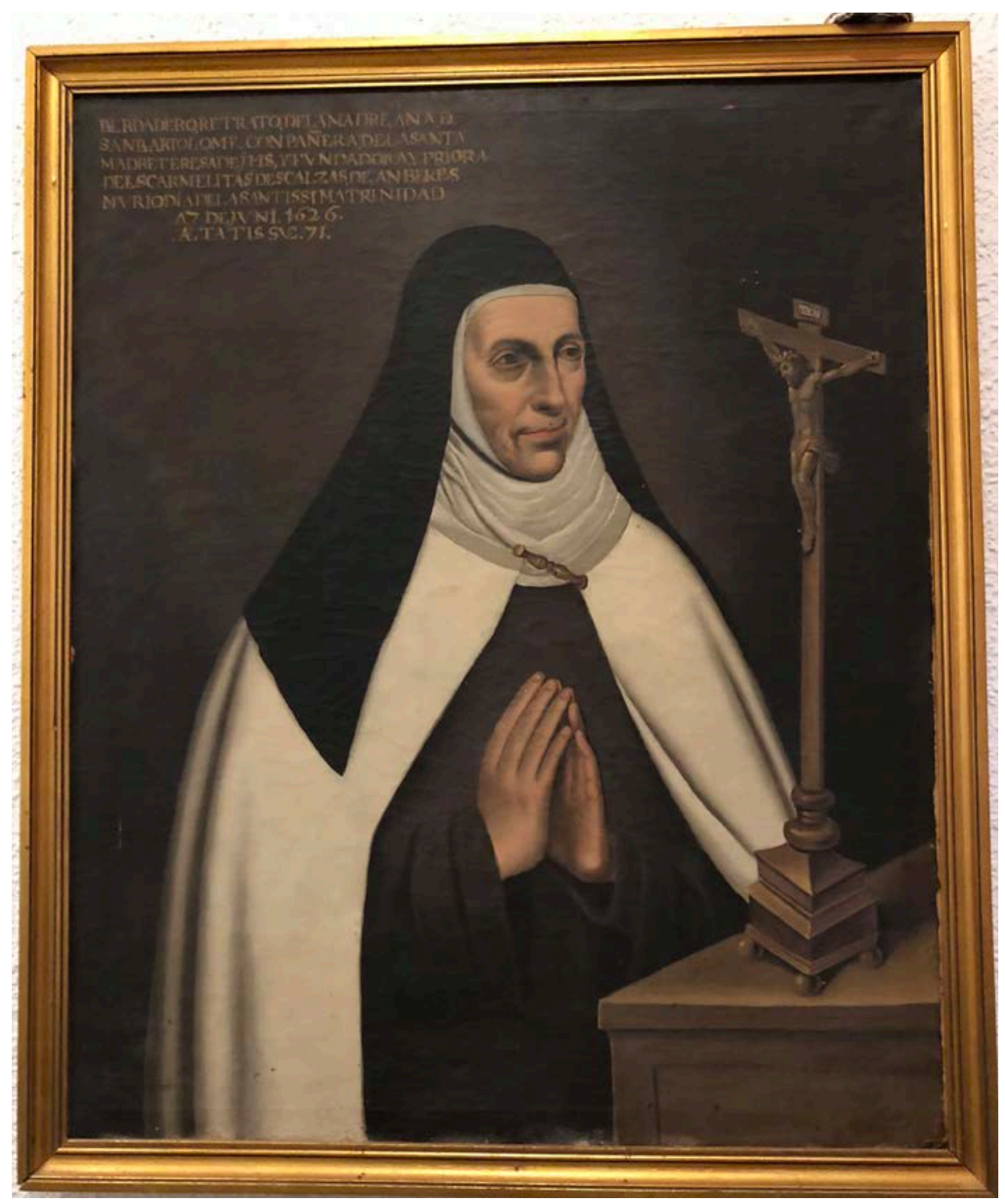

Figura 8. Anónimo. Óleo sobre lienzo. Berdadero Retrato de Ana de San Bartolomé. Siglo XII. Carmelitas Descalzos de Alba de Tormes. [Fotografía: Tomás C. Peña, Julián Barrera Miguel, Agustín Herrero (Casas, 2018, p. 315]. 
En esta Contemplación del Crucificado se describe una imaginación que el lector percibe como corpórea; se recrea una imagen mental en la que la narradora se introduce con los ojos, intima y compadece -observó fray Matías- exigiendo lo mismo al lector, quien así puede imaginar la figura descrita como la escultura que aparece en el Berdadero retrato. Antes de referirse al Cuerpo, y al final, para cerciorar su poder de conducción a la 'visión intelectual, la narradora alude al silencio con el cual se apela a la vía negativa de la espiritualidad: "Que esta es gran virtud: el callar cuando las cosas nos dicen que son verdá". También en la pintura del Berdadero retrato callan las figuras casi aisladas de Cristo y Ana, con los labios sellados. Interactúan quietas a través del sentido que cobra el gesto y la mirada de oración: medios por los que la monja, según las prácticas religiosas, obtiene de la imaginería la respuesta muda deseada: "sin hablar, hablabas, y sin hablar, obrabas los misterios a que habías venido". 45

Este Señor que os vino a redimir os dio licencia de que entrásedes en sus divinas carnes y hicieses agujeros, $\mathrm{pa}(\mathrm{ra})$ que fuesen nuestro refugio y morada y que nuestros padres pasados hiciesen en esas preciosas llagas nidos de refugio para sus niños, como las aves hacen de los árboles. Vos, Señor, sois el Árbol de la Vida, y como en el madero de la cruz se habían de celebrar las bodas y desposorio con vuestra iglesia.

A través de la contemplación de la Cruz como árbol de la vida, se desencadena en el texto una recreación mental y sintética del ciclo de Pasión, que estaciona en detalles visuales del padecimiento. La narradora recorre el Cuerpo como si su escritura fuese una cámara de vídeo. Como en el Berdadero retrato, las imágenes se abstraen en el texto hasta convertirse en figuras simbólicas: "los clavos (...) son las puertas, pa(ra) entrar en el reino de Dios. Fuentes de vida que son estas preciosas llagas". El pecado de los hombres liga a Cristo al madero, "y desta unión se hizo la que deseábades hacer, Señor mío, con vuestra esposa la Iglesia". La pompa de bodas son los signos de "dolores y desprecios", seña de autenticidad del enlace. La mirada (se) recrea (en) la imagen de un cuerpo nupcial, cuyas galas son "gotas de sangre como piedras preciosas, y ansí, Señor, salís en público y os mostráis verdadero enamorado". Estas similitudes amorosas, hasta masoquistas, dotan a los símbolos de una significación ortodoxa y promueven la realización de la imagen en la sociedad conventual: "que tomemos la cruz y que os sigamos". ${ }^{46}$ Esa contemplación del Sacrificio no es estática sino camino de sufrimientos imaginarios que quieren conducirse hacia la comunión mística. En el cuadro, la oración visual atraviesa la distancia pintada de negro que separa los ojos de Ana de los de la escultura de Cristo, unidos ambos por ese diálogo gestual que transforma el dolor en el placer expresado por la sonrisa de la monja: la imagen del Cuerpo doliente adquiere el sentido redentor de la pasión con que se contempla: "¡es posible, Señor, que os quiere ansí vuestra esposa?". La narradora se ampara en autoridades que explican estos misterios: "San Buenaventura dice que toda su ciencia la aprendió mirando un Cristo en la cruz y otros dicen lo mesmo; Teresa de Jesús se habla desta devoción que ella tuvo siempre y que aconseja a sus hijas que no salgan deste camino". Así el Cristo de imaginería o imaginado es la estructura figurativa o locus en la memoria de las monjas descalzas y andariegas que, aun recluidas en la celda, recorren la imagen del Cuerpo con "ojos del corazón: que sin fe no podemos caminar por este camino real de los divinos misterios". La meditación focalizada en esa imagen del dolor lleva a una especie de deriva sensual; el recorrido penitencial por la degradación del cuerpo es recompensado por el gozo de seguir "este camino

45 Otros escritos de la beata inciden en la idea de diálogo visual: “¡Oh, dulce Jesús,/ Nuestro bien y gozo!/ Dadme vuestra luz,/ Mírenme tus ojos.//Jesús me miró/ Y yo le miré./ Díjome: Yo, yo/ Por ti moriré”. Ana de San Bartolomé, Dulce Jesús, poesía de 1607-1611, en Urkiza (1981, pp. 707-708).

46 De nuevo el psicoanálisis da una explicación al goce de estos dolores basada en mecanismos miméticos: “El juego y la imitación artísticos practicados por los adultos, a diferencia de la conducta del niño, apuntan a la persona del espectador, no ahorran a este último las impresiones más dolorosas (en la tragedia, por ejemplo), no obstante lo cual puede sentirlas como un elevado goce" (Freud, 1992, p. 17). 
verdadero", camino de imitación, "camino de la cruz, camino real pa(ra) ir al cielo", que se hace reciclando imágenes, "aprovechándose de los frutos de la sagrada Pasión de Jesucristo".

\section{Recapitulación}

Muchas investigaciones se han ocupado de la relación de las visionarias con las imágenes artísticas, y desde la historia del arte se ha tratado de comprender este recurso como 'más que herramienta útil en las prácticas religiosas'. Lucía Lahoz, al señalar la profusión e implicaciones de las alusiones a la visión en los textos de Teresa de Ávila, explicitando la apertura del término 'imagen' a lo mental e inmaterial, ha señalado las diferencias e imbricación entre el imaginario y la imaginería, en la configuración de una imagen central en las prácticas religiosas impulsadas por tradiciones medievales. Ana, como Teresa, protagoniza imágenes hechas por otros y las produce: es objeto y agente de biografía en-y de imágenes. No obstante, los contextos socio-psicológicos enmarcan cada estudio en unas coordenadas concretas. También las distinciones que han subrayado las investigaciones de Hans Belting han servido para organizar teóricamente los materiales de este ensayo, y presentar un análisis de las imágenes de- y en Ana de San Bartolomé: miradas que parten de-y se dirigen al cuerpo medial de la visionaria. Ana es autora-personaje en textos y obras plásticas, y a través de esas representaciones hemos procurado fragmentar el proceso por el que llega a convertirse en imagen; no es la única manera de hacerlo.

Para terminar, sólo queda recordar que la ceguera que la autora de la Autobiografía dice que rinde a sus visiones, esa obediencia a la imaginación que afirma una existencia, convierte en positiva la que, en principio, era negación de su voluntad en la visión, en el entendimiento y la palabra de un cuerpo autómata. A través de ese cuerpo, que siguió obrando milagros tras la muerte de Ana desde el relicario de Amberes, veía y actuaba el Señor expresándose con motivos ideológicos que respondían a voluntades humanas en un momento bélico. La recompensa por su 'amor al Cuerpo', además, fue para su alma y según lo esperado en base a esa ideología que precisamente censura el cuerpo y su degeneración: "Non dabis sanctam tuam videre corruptionem" (cita del misal romano del oficio de Semana Santa) es la súplica de la estampa de Alexander Voelt (fig. 9) que la representa ab Angelis Transportata, llevada al ideal incorpóreo e incorruptible de la Verdadera Imagen, al fin de un camino de imitación. 


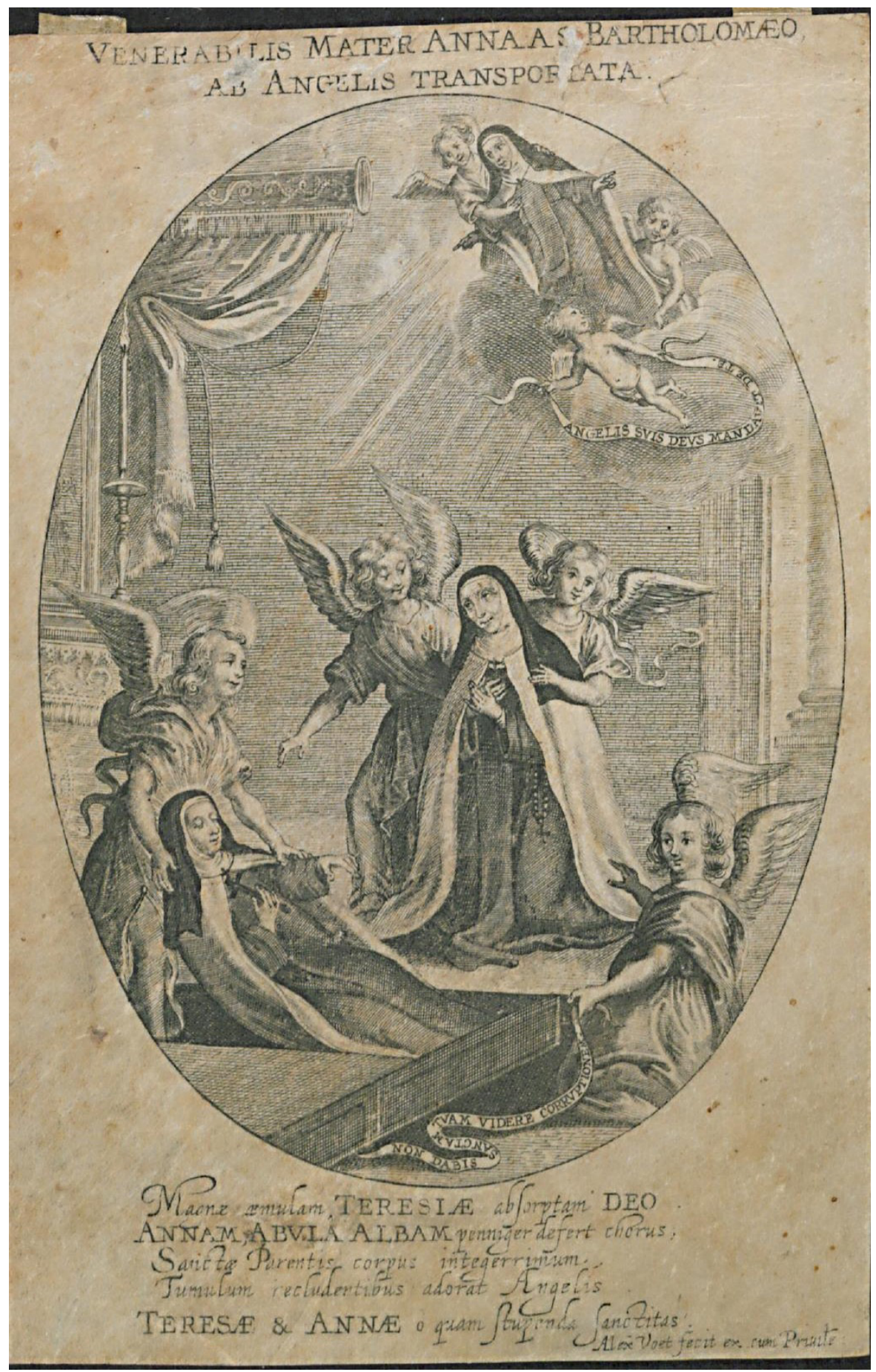

Figura 9. Alexander I Voet. Estampa. Venerabilis mater Anna a S. Bartholomaeo ab angelis transportata. 1628. Biblioteca de la Universidad de Amberes, RG PK: Thijs KP 1.10. [Fotografía: Biblioteca de la 


\section{Q Bibliografía}

"Acebrón, J. (2004). Sueño y ensueño en la literatura castellana medieval y del siglo XVI. Cáceres: Universidad de Extremadura.

" Alcoy, R. (2017). Anticipaciones del Paraíso. El donante y la migración del sentido en el arte del occidente medieval. Vitoria: Sans Soleil.

》Atienza, A. (2015). En permanente construcción. La recreación de la figura de Santa Teresa en las semblanzas biográficas de sus hijas. Hispania Sacra, 136, 575-612.

" Atienza, A. (2016). 'Nosotras, ellos, nuestra orden': Una revisión en torno a los tiempos fronterizos en el Carmen Descalzo, c. 1585-1596. En J. L. Betrán, B. Hernández y D. Moreno (Coords.), Identidades y fronteras culturales en el mundo ibérico en la Edad Moderna (229-242). Bellaterra: Universidad Autónoma de Barcelona.

» Belting, H. (2012 [2002]). Antropología de la imagen. Madrid: Katz.

» Belting, H. (2011 [2006]). A verdadeira imagem. Porto: Dafne.

》Blanchot, M. (1969 [1959]). El libro que vendrá. Caracas: Monte Ávila.

》 Burke, P. (2008). Cómo interrogar a los testimonios visuales. En J. L. Palos y D. Carrió (Eds.), La historia imaginada: construcciones visuales del pasado en la Época Moderna (2940). Madrid: Centro de Estudios Europa Hispánica.

"Caro Baroja, J. (1985). Las formas complejas de la vida religiosa (Religión, sociedad y carácter en la España de los siglos XVI y XVII). Madrid: Sarpe.

»Casas, M. (Coord.). (2018). Vítor-Teresa. Teresa de Jesús, doctora honoris causa de la Universidad de Salamanca. Cat. exp. Salamanca: Diputación de Salamanca.

»Cilleruelo, L. (Trad.). Obras Completas de San Agustín. Federación Agustiniana Española y la Biblioteca de Autores Cristianos, www.augustinus.it/spagnolo (Acceso: 26 de enero, 2019).

"Cruz, A. J. (2016). Las formas de vida religiosa femenina en la época de Teresa de Jesús y Catalina de Cardona. eHumanista, 33, 246-265.

》De Jesús Sacramentado, F. (1976). Ana de S. Bartolomé: autenticidad de algunos escritos discutidos. Ephemerides Carmeliticae, 27, 263-289.

"De la Cruz, J. (1628). Obras Espirituales que encaminan a una alma a la perfecta unión con Dios. Alcalá: Viuda de Andrés Sánches.

"De la Pascua, M. J. (2019). El Carmelo como jardín: del hortus conclusus al hortus theologicus en el paisaje espiritual de Teresa de Jesús y María de San José (1526-1603). Arenal, $26(1), 35-65$.

"De Melgar y Abreu, B. (1917). Diez y seis cartas autógrafas é inéditas de la beata Ana de San Bartolomé compañera y secretaria de Santa Teresa de Jesús. Madrid: Fortanet.

»Del Niño Jesús, F. (1917). La Beata Ana de San Bartolomé, compañera y secretaria de Santa Teresa de Jesús (compendio de su vida). Burgos: Monte Carmelo.

"Del Niño Jesús, M. (1944). Manuscrito inédito de la Beata Ana de San Bartolomé. Revista de Espiritualidad, 3, 79-87.

"De San Juan de la Cruz, G. (1914). Obras del Místico Doctor Juan de la Cruz. Edición crítica, III. Toledo: Viuda e Hijos de J. Peláez. 
»Díaz Díaz, T. (2015). El tratamiento de la figura de Santa Teresa de Jesús en la filmografía española. En F. J. Campos y Fernández de Sevilla (Coord.), Santa Teresa y el mundo teresiano del Barroco (711-726). Madrid: Centro Universitario Escorial-María Cristina.

» Ditchfield, S. R. y Smith, H. (Eds.). (2017). Conversions: Gender and Religious Change in Early Modern Europe. Manchester: Manchester University Press.

» Ditchfield, S. R. (2017). Translating Christianity in an Age of Reformations. Studies in Church History, 11, 164-195.

»Ferrús, B. (2008). Crea que andamos hechizadas la una con la otra. Mujeres en el entorno de Santa Teresa (cuerpos y almas). Scriptura, 19-20, 57-73.

» Freud, S. (1992 [1976]). Más Allá del principo del Placer. Psicología de las Masas y análisis del Yo, y otras obras (Colección Sigmund Freud. Obras completas, XVIII). Buenos Aires: Amorrortu.

» Garrido, P. (1999). El tema del reconocimiento en el teatro español del siglo XVI: la teoría de la anagnórisis. Madrid: Tamesis.

» González De Ávila, M. (2010). Cultura y razón. Antropología de la literatura y de la imagen. Barcelona: Anthropos.

» Herpoel, S. (1999). A la zaga de Santa Teresa: autobiografias por mandato. Amsterdam: Rodopi.

» Herranz Velázquez, F. (2017). Nuevas aportaciones al debate historiográfico sobre el linaje de Santa Teresa de Jesús. En E. Cutillas (Coord.), Nuevas aportaciones en la investigación en Humanidades. VI Jornadas de Investigación de la Facultad de Filosofía y Letras de la Universidad de Alicante (107-114). Murcia: Compobell.

» Howe, E. T. (2015). Autobiographical Writing by Early Modern Hispanic Women. Nueva York: Routledge.

» Ibáñez, A. C. y Payo, R. J. (2000-2002). La iglesia del convento de Madres Carmelitas de San José y Santa Ana de Burgos, B.I.F.G. Burgos, LXXVIII (9, 221), 267-297.

» Kris, E. y Kurz, O. (1982 [1934]). La leyenda del artista. Madrid: Cátedra.

» Lahoz, L. (2005). La imagen de la mujer en el arte medieval. En M. Carmen Sevillano et alii (Coord.), El conocimiento del pasado: una herramienta para la igualdad (255-294). Salamanca: Plaza Universitaria.

» Lahoz, L. (2015). Santa Teresa y las imágenes: el peso de las prácticas y estrategias femeninas tardomedievales. En M. Casas (Ed.), Teresa (29-40). Salamanca: Catedral.

" Lahoz, L. (2019). Santa Teresa: El imaginario, la imagen y la imaginería. En M. Casas (Coord.), Vítor Teresa. Teresa de Jesús, doctora honoris causa de la Universidad de Salamanca (170-193). Salamanca: Diputación Provincial.

» López de Munain, G. (2018). Máscaras mortuorias. Historia del rostro ante la muerte. Vitoria-Gasteiz: Sans Soleil.

» Louth, A. (1998). Apophatic Theology. Denys the Aeropagite. Hermathena, 165, 71-84.

» Mañero, M. P. (1991). Cartas de Ana de san Bartolomé a Monseñor Pierre de Bérulle, Criticón, 51, 125-140.

» Mirzoeff, N. (2003 [1999]). Introducción a la Cultura Visual. Barcelona: Paidós.

» Mitchell, J. T. W. (2009 [1994]). Teoría de la imagen. Ensayos sobre representación verbal y visual. Madrid: Akal.

» Moralejo, S. (2004). Formas elocuentes. Reflexiones sobre la teoría de la representación. Madrid: Akal. 
» Morrás, M. (2015). Ser santa y mujer (Península Ibérica, siglos XV-XVII). Medievalia, 18 (2), 9-24.

» Mujica, B. (2001). Beyond Image: The Apophatic-Kataphatic Dialectic in Teresa de Ávila. Hispania, 84(4), 741-748.

» Mujica, B. (2014). Healing on the Margins: Ana de San Bartolomé, Convent Nurse. Early Modern Studies Journal, 6 (Women's Writing/Women's Work in Early Modernity), 128-165.

» Muñoz, E. (2018). Retrato de Ana de San Bartolomé. En M. Casas (Coord.), Vítor Teresa. Teresa de Jesús, doctora honoris causa de la Universidad de Salamanca (314-315). Salamanca: Diputación.

» Muñoz, E. (2020). Historia y devoción en imágenes de una conversación celeste (OCD, Desierto de Las Batuecas, s. XVII). Philostrato, 7, en prensa.

» Peña, Á. (2012). La Beata Sor Ana de San Bartolomé, una maravilla de Dios. Lima: Agustinos Recoletos.

"Portús, J. (1999). Retrato, humildad y santidad en el Siglo de Oro. Revista de dialectología y tradiciones populares (Lo constante y lo nuevo en la religiosidad española: Las culturas superpuestas), 54(1), 169-188.

» Portús, J. (2011). La convivencia con las imágenes en el siglo de Oro. En N. Campos (Coord.), Barroco andino. Memoria del I encuentro internacional (37-47). Pamplona: Fundación Visión Cultural, Universidad de Navarra.

»Ramírez, J. A. (2002). Dalí: Lo crudo y lo podrido. Madrid: Antonio Machado.

"Rodrigo, C. (2015). Visión de Santa Teresa en el Museo de Bellas Artes de Valencia. En F. J. Campos y Fernández de Sevilla (Coord.), Santa Teresa y el mundo teresiano del Barroco (645-660). Madrid: Centro Universitario Escorial-María Cristina.

» Ruiz, A. M. y Urkiza, J. (2016). Vida en imágenes de Ana de San Bartolomé. Burgos: Monte Carmelo.

》 Ruiz de Loizaga, M. (2015). Santa Teresa en el lenguaje pictórico de las vanguardias. En F. J. Campos y Fernández de Sevilla (Coords.), Santa Teresa y el mundo teresiano del Barroco (711-726). Madrid: Centro Universitario Escorial-María Cristina.

» Sánchez, M. (1990). Las recreaciones en el Carmelo: Ana de San Bartolomé (Análisis de una Conferencia Espiritual). AISO, Actas II, 931-929.

"Sánchez, R. (2008). De la cabeza al corazón: cuerpos femeninos, arte contemporáneo e historia de la cultura medieval. SEMATA, Ciencias Sociais e Humanidades, 20, 299-327.

"Sanmartín, R. (2015). En torno al arte y las visionarias. Medievalia, 18(2), 257-367.

》Schmitt, J. C. (1999). El historiador y las imágenes. Relaciones 77, 20, 17-47.

»Stein, E. (1994). La ciencia de la Cruz. Estudio sobre Juan de la Cruz. Burgos: Monte Carmelo.

» Torres, C. (1995). Ana de Jesús. Cartas (1590-1621) Religiosidad y vida cotidiana en la clausura femenina del Siglo de Oro. Salamanca: Universidad de Salamanca.

"Urkiza, J. (1981). Obras completas de la Beata Ana de San Bartolomé. Roma: Instituto Teresianum.

»Urkiza, J. (2006). Ana de San Bartolomé e Isabel Clara Eugenia. Dos mujeres dirigentes de la vida social y religiosa en Flandes (Entre treguas y guerras buscando la paz). Monte Carmelo, 114, 319-380.

»Urkiza, J. (2008). Soldados españoles de Flandes y sus mujeres bajo el amparo espiritual y solidario de Ana de S. Bartolomé. Monte Carmelo, 116, 165-202. 
»Valero, A. C. (2014). Arte e iconografía en los conventos carmelitas en la provincia de Valladolid (Tesis Doctoral). Valladolid: Universidad de Valladolid.

»Weber, A. (2005). El feminismo parcial de Ana de San Bartolomé. En L. Vollendorf (Coord.), Literatura y feminismo en España (s. XV-XXI) (77-94). Barcelona: Icaria.

»Yuste, B. y Rivas-Caballero, S. L. (2004). Ana de San Bartolomé y la expansión del Carmelo Descalzo. Revista de Espiritualidad, 63, 301-345. 